\title{
PRISÃO PREVENTIVA: DIREITOS FUNDAMENTAIS E A GARANTIA DA ORDEM PÚBLICA
}

PRISÃO PREVENTIVA: DIREITOS FUNDAMENTAIS E A GARANTIA DA ORDEM PÚBLICA

\section{Gregório Edoardo Raphael Selingardi Guardia}

\begin{abstract}
Resumo:
O amplo rol de direitos fundamentais inscritos na Carta Maior representa considerável aperfeiçoamento do sistema jurídico brasileiro e, muitas vezes, denota verdadeira ruptura com o preconizado em diplomas constitucionais anteriores. A atual Carta Magna admite, contudo, as medidas cautelares restritivas de liberdade. Imperioso redargüir, pois, se tal custódia, quando decretada com fulcro na garantia da ordem pública, cuja previsão legal remonta à década de 1940, compatibiliza-se com a normativa constitucional hodierna. Desse modo, diante das sucessivas modificações legislativas e constitucionais implementadas desde o advento do Código de Processo Penal, imprescindível questionar o que se entende por garantia da ordem pública. Investiga-se, pois, o fim desta modalidade de prisão provisória, bem como refletese acerca da possibilidade de reconhecê-la constitucional e necessária, a partir da seguinte indagação: Como discipliná-la, à luz dos direitos e garantias fundamentais preconizados pelo legislador originário de 1988 ?
\end{abstract}

Palavras-chave: Direitos fundamentais. Medidas cautelares restritivas de Liberdade. Prisão Preventiva. Garantiada Ordem Pública.

\begin{abstract}
:
The broad list of fundamental rights enshrined in the Charter represents a considerable improvement Staff of the Brazilian legal system and often denotes real break with the recommendations in previous constitutional texts. The current Constitution does, however, the restrictive measures of freedom. Imperious reproof, for if such custody when ordered with fulcrum in ensuring public order, which legal provision dates back to the 1940 s, is compatible with the today's constitutional norms. Thus, before the successive legislative and constitutional changes implemented since the advent of the Code of Criminal Procedure, essential question what is meant to guarantee public order. Is investigated, since the end of this form of provisional detention, and reflected on the possibility of recognizing it constitutional and necessary, as the following question: How to discipline her in the light of fundamental rights and safeguards recommended by the legislature originating in 1988 ?
\end{abstract}

Keywords: Fundamental rights. Precautionary measures restrictive of freedom. Preventive detention. Guarantee of public order.

Aluno do Curso de Graduação da Faculdade de Direito da Universidade de São Paulo. 


\section{Prisão provisória e Direitos Fundamentais}

Durante séculos, ao menos, a prisão preventiva mantém-se como tema recorrente nos debates acadêmicos, nada obstante se possa afirmar que suas origens remontam à Antiguidade. Homens de diferentes continentes, culturas e interesses dedicaram-se à análise deste signo ainda tão caro à processualística coetânea. Tratase, como será visto adiante, de medida excepcional, de natureza cautelar - judicial, instrumental, urgente, provisória e aparente - condicionada a estritos pressupostos de admissibilidade e tolerada apenas nas situações especificamente previstas em lei.

Ressoa da atual constitucionalização dos direitos individuais que 0 ordenamento jurídico deve concretizar os anseios de todos os homens e de cada homem, permitindo seu pleno desenvolvimento. As situações são várias e exigem normas distintas para Estados distintos. Caberá ao legislador determinar os bens que devem ser priorizados em determinada sociedade e tempo. Contudo, o legislar encontra limites no homem, na Pessoa Humana. Afinal, o Direito existe em virtude da pessoa e não o contrário. O ser humano é o fundamento primeiro e a causa final do Direito. Logo, o respeito ao homem e à sua liberdade são limites impostos a qualquer legislador.

As concepções de liberdade esposadas pelo Direito contemporâneo, por sua vez, deitam raízes no pensamento filosófico. Em linhas gerais, as definições elaboradas pelos juristas têm como objetivo afirmar o valor humano e a supremacia do homem em relação aos outros seres.

A liberdade não é um predicado humano, mas parte do próprio homem. Ser livre é ser dono de si mesmo e poder agir como tal. O homem não se submete a valores absolutos capazes de determinar seu agir; é livre. Descobre-se existindo e tem que escolher o que fará de seu ser.

Contudo, essa liberdade não é irrestrita. Encontra limites impostos pelo convívio social. O ser humano, na perspectiva existencialista de Sartre, 'é considerado um legislador pronto a eleger: suas opções afetam não apenas a si, mas a toda a humanidade. A autonomia pressupõe a responsabilidade. Consequentemente, plausível e necessário restringir-se a liberdade ambulatória daqueles que agem em flagrante desrespeito aos mais caros valores humanos positivados.

A custódia in carcelum, provisória ou definitiva, representa medida extrema e violenta, última instância a que se deve acorrer para a salvaguarda da paz social. Cabe ao legislador constitucional disciplinar de maneira inequívoca as hipóteses em que se admite o encarceramento e impedir que as prisões se convertam em instrumentos políticos de repressão. No Brasil, a Constituição Federal prima pelo respeito à dignidade da pessoa

SARTRE, Jean-Paul. L'Existencialismme est um Humanisme. São Paulo: Abril Cultural, 1973. p. 15. 
humana, e ao tratar dos direitos e garantias fundamentais, dispõe exaustivamente sobre a igualdade; a presunção de inocência; o devido processo legal; a legalidade; a ampla defesa e tantos outros princípios imprescindíveis à manutenção das liberdades individuais.

A Carta Constitucional, ainda, reconhece expressamente os direitos e garantias decorrentes dos tratados internacionais em que o Estado seja parte, conforme o disposto no art. $5^{\circ}$, parágrafos $2^{\circ}$ e $3^{\circ}$ No que concerne à matéria processual penal, insta mencionar o Pacto Internacional sobre Direitos Civis e Políticos, de 1966, promulgado pelo Presidente da República, por intermédio do Decreto n. 592/92, e a Convenção Americana sobre os Direitos Humanos (Pacto de São José da Costa Rica), de 1969, que passou a integrar o ordenamento brasileiro por força do Decreto n. 678/92.

Ambos os estatutos tratam do direito à liberdade e ampliam o extenso rol de direitos e garantias ínsito no art. $5^{\circ}$, da Constituição Federal. O art. $7^{\circ}$, do Pacto de São José, nos parágrafos $2^{\circ}$ e $3^{\circ}$, não apenas veda a detenção e o encarceramento arbitrários, mas condiciona a privação da liberdade física a uma expressa previsão constitucional e legal. Impõe, também, que estas leis sejam compatíveis com a Constituição vigente. O Pacto Internacional sobre Direitos Civis e Políticos merece particular deferência, ao dispor expressamente sobre a prisão preventiva, tema desta tese de láurea. Nos termos do parágrafo $3^{\circ}$, do art. $9^{\circ}$, deste diploma, a prisão preventiva deve ser admitida apenas em caráter excepcional.

A decretação da custódia preventiva, portanto, condiciona-se à subsunção do fato à(s) hipótese(s) inscrita(s) na norma e a uma estrita observância, in concreto, de dois pressupostos de admissibilidade: o fumus commissi delicti e o periculum libertatis. Diante da materialidade do delito e da existência de suficientes indícios de autoria, necessário aferir ainda se o encarceramento é imprescindível à instrução processual ou à aplicação da lei penal.

Consoante descrito no art. 312, do Código de Processo Penal Brasileiro, a prisão preventiva tem por finalidade garantir a ordem pública, a ordem econômica, assegurar a aplicação da lei penal e facilitar a instrução criminal. Trata-se de enunciação taxativa, verdadeiro numerus clausus que não admite interpretação extensiva. Não há que falar, em matéria penal, no poder geral de cautela do magistrado ou em encarceramento compulsório, práticas revelhas, de há muito proscritas da normativa nacional.

Ainda que a legislação processual brasileira enumere as situações em que se admite a prisão preventiva, o texto legal é equívoco e dá azo a incontáveis interpretações, especialmente no que se refere à garantia da ordem pública. Sob distintas inspirações filosóficas, religiosas, jurídicas, econômicas e políticas foram formuladas inúmeras definições de ordem pública. Desta barafunda conceitual, forçoso reconhecer que a ordem pública é um dos mais elevados cânones do processo penal contemporâneo e, concomitantemente, um dos mais obscuros. 
Sob este discrímen têm sido legitimadas, há décadas, as mais diversas hipóteses de prisão preventiva. Após breve análise doutrinária e jurisprudencial (itens 3.2.4 e 3.3) será possível identificar decretos de prisão preventiva fundados na garantia da ordem pública por aspectos relacionados ao delito, ao agente ou ao processo. $O$ caráter hediondo do crime perpetrado, por si só, é capaz de ensejar restrições à liberdade individual. Também, o imenso clamor público gerado pela conduta do agente; a expectativa de que ao se livrar solto possa dar continuidade à prática delitiva ou reiterar a ação criminosa; a impossibilidade de garantir-se-lhe a integridade física fora do cárcere; a periculosidade revelada por seu comportamento pregresso. Ainda estão mencionadas a garantia do cumprimento de eventual sentença condenatória; a prevenção da violência através da intimidação de criminosos e a manutenção da credibilidade do Poder Judiciário, que restaria comprometida caso o imputado permanecesse fora do cárcere. E mesmo nas situações em que a soltura do agente representa ameaça às vítimas e testemunhas subsumidas ao fundamento da custódia cautelar por conveniência da instrução criminal - por vezes invoca-se como supedâneo legal a garantia da ordem pública.

Ao inserir tal conceito indeterminado no rol taxativo de hipóteses em que se admite a prisão preventiva, acabou o legislador por alargar inadvertidamente as balizas impostas à hermenêutica legal. Inadmissível, portanto, mais de vinte anos após a promulgação da atual Carta Constitucional, subsista sem consideráveis alterações o art. 312, do Código de Processo Penal, verdadeiro numerus apertus a regulamentar a prisão preventiva.

\section{Medidas Cautelares restritivas de liberdade}

O fim a ser alcançado pelo Processo Penal transita pela incerteza de futura comprovação, descomprovação ou inconclusão acerca da materialidade e autoria delitivas. Trata-se de percurso da Justiça que culminará com a absolvição ou condenação do réu, iter que longe de oferecer prognóstico seguro, exemplifica risco inerente ao Processo Penal. ${ }^{2}$

O tema da cautelaridade pode apresentar-se ardiloso se não se atentar ao cerne desta problemática no Processo Penal: o escopo de evitar um perigo concreto que seja apto a impossibilitar a apuração da verdade e o provimento justo. Assim, se desavisadamente mirarmos a problemática da cautelaridade por alguma de suas consequências práticas e olvidarmos seu fundamento, estaremos nos afastando também do comprometimento do operador do direito de admitir a restrição da liberdade como medida excepcionalíssima.

Se conhecido o tema da cautelaridade por intermédio da constatação da sujeição da pessoa ao cárcere, será possível pensar, v.g., que a medida provisória se trata

BARROS, Romeu P. de Campos. Processo penal cautelar. Rio de Janeiro: Forense, 1982. p. 184. 
de antecipação da pena, por ter aparente resultado prático idêntico ao de uma sentença condenatória. Todavia, na verdade, apenas a consequência imediata é a mesma, já que, os fundamentos e limites destas restrições da liberdade diferem entre si. Igualmente, refletir que o tempo da prisão provisória é computado na pena definitiva, levaria a imaginar que esta medida se baseia em uma concreta antecipação da sanção, quando se trata somente de aplicação do princípio humanizador da equidade.

Os esforços do legislador e do intérprete do Direito deverão concentrar-se, pois, respectivamente, na estrita normatização da cautela, com o fito de evitar subjetivismos, bem como na estrita cognição. Tudo isto, sem perder de vista que o risco representado pelo processo incumbe majoritariamente ao Estado; tratando-se de desproporção intervir no status libertatis do sujeito antes de criteriosa análise da necessidade e conveniência da medida.

Evidente, pois, que Estado e Pessoa Humana não dispõem de meios equivalentes de atuação na relação processual; a desproporção é tanta e de tal sorte evidente que sempre preocupou à doutrina, a construção por meio da dinâmica do favor rei, de uma real paridade no Processo Penal.

\subsection{Cautela e liberdade}

Muito embora a Carta constitucional de 1988 não tenha acolhido expressamente o princípio da intervenção mínima do Direito Penal, não há questionar que este pode ser aduzido como decorrência do direito à liberdade. Desse modo, o bem jurídico protegido no caput, do art. $5^{\circ}$ da Constituição Federal, somente será relativizado diante de elevada necessidade prevista em lei. O exagerado desvalor de uma ação, de seu resultado, e a reprovabilidade da conduta do autor, justificam, assim, a excepcional atuação do Direito Penal na imposição da pena, enquanto único meio hábil de proteção suficiente da ordem social diante de ataques relevantes. ${ }^{3}$

Desde já elucidamos que a prisão decorrente de pena difere da prisão cautelar em variados aspectos que serão apresentados a seguir. Contudo, ambas coincidem na estrita excepcionalidade dos casos em que podem ser aplicadas: enquanto a pena tão somente será imposta após o trânsito em julgado da sentença condenatória da qual não couber mais recurso - observado o devido processo legal -, a medida cautelar não será adequada se deixar de preencher qualquer de suas condições (pressupostos, requisitos e limites).

A legitimidade da prisão preventiva, por conseguinte, restringe-se ao mínimo de casos, exigindo graves fundamentos - com previsão legal - que devem se

MIRABETE, J. F. Manual de direito penal. 17. ed. São Paulo: Atlas, 2001. p. 119-120. v. 1. 
compatibilizar com a diretriz da intervenção mínima, cercando o inculpado de todas as garantias jurisdicionais.

A prisão preventiva diz respeito à privação da liberdade pessoal imposta no curso da persecução penal; medida que anterior à sentença definitiva, constitui desvantagem provisória à pessoa humana. Trata-se de anulação temporária do status libertatis, desde o momento em que decretada até enquanto subsistentes os fundamentos da medida judicial. ${ }^{4}$

Observe-se que a manutenção de qualquer prisão provisória deve respeitar também os prazos legais; imperativo, assim, que estes sejam claros e objetivos, possibilitando o investigado seja julgado em tempo razoável ou posto em liberdade, como disposto no Pacto Internacional sobre Direitos Civis e Políticos de 1966, art. $9^{\circ}$ 3, e na Convenção Americana sobre Direitos Humanos - Pacto de São José da Costa Rica, art. $7^{\circ}$ 5. Neste sentido, tais diplomas demonstram os esforços empreendidos pela ordem internacional com o fito de minimizar o prazo da custódia cautelar e adequá-la ao mínimo necessário; induvidoso que dilações indevidas resultam sofrimentos morais e físicos aos imputados e comprometem a almejada dinâmica favor rei do processo penal.

A partir do exposto, é possível a identificação de cinco características essenciais e comuns a todas as modalidades de prisão preventiva: medidas judiciais, instrumentais, urgentes, provisórias e aparentes.

Destarte, tão somente por meio de manifestação judicial da autoridade competente - e consoante o princípio do juiz natural - poderá ser decretada a custódia preventiva, expressão do poder-dever do magistrado. A instrumentalidade pode ser vislumbrada pela natureza jurídica subsidiária da medida em relação ao principal. $\mathrm{O}$ aspecto concernente à urgência revela-se no nexo entre a medida acautelatória e sua adequação para sanar uma situação iminente (periculum in mora). A provisoriedade, por sua vez, delimita a duração da medida cautelar no tempo, porquanto, a privação da liberdade, assim como seu prolongamento, repercute como gravame indelével em desfavor do imputado. Por fim, a aparência de direito do ato está sustentada pelo rol probatório (fumus boni juris).

\footnotetext{
4 , Carlo Umberto Del Pozzo expressa posicionamento diverso ao consignar que a privação do status libertatis prolonga-se "a) fino al confluire della misura provisoria nella pena definitiva, con l'inizio dell'esecuzione; b) of fino alla liberazione od alla scarcerazione per le altre cause previste dalla lege" (DEL POZZO, Carlo Umberto. La liberta personale nel processo penale italiano. Torino: UTET, 1962. p. 30). Nada obstante as duas hipóteses apontadas pelo autor constituam marcos temporais desconstitutivos da prisão preventiva, não se trata de definição consentânea com a provisoriedade da medida cautelar. Importa ressaltar que o autor entende a prisão preventiva como medida relativamente permanente, posicionamento colidente com o perfilhado neste estudo, das medidas cautelares não como reação ao provável injusto penal, mas sim, como proteção dos fins que o processo persegue. Portanto, ressaltamos que o lapso temporal da medida deve estar estritamente jungido ao periodo em que persistirem os fundamentos da medida, respeitando-se também o prazo máximo estipulado em lei.
} 
Nada obstante as características mencionadas constituam base conceitual pouco questionada na doutrina hodierna, não se pode perder de vista os ensinamentos de autores que apregoam o caráter da prisão preventiva como pena. ${ }^{5}$ Assim, sob a égide da estrutura inquisitória de processo, a custódia visa colocar o réu ao dispor do procedimento, sendo sua confissão o intuito verdadeiro da medida. Gian Domenico Pisapia, ao expor a lógica inversa da persecução medieval, assevera que a detenção do imputado constituía indispensável operação preliminar para a imposição da tortura e consequente obtenção da confissão. ${ }^{6}$

A encarceração preventiva no período medieval, como leciona o mencionado autor, representava sofrimento imposto ao acusado para que se arrependesse da increpação; prática perpetrada pela Igreja, em que o simples conteúdo da incriminação já era suficiente para a custódia preventiva. Cuida-se do legado de uma visão religiosa do processo, a exigir que a pessoa sobre a qual recaia uma suspeita grave esteja sujeita a mortificação física e espiritual. Destaca-se, no contexto apresentado, a miscividade entre os conceitos de investigado e de réu, que em muitos casos implica privação arbitrária da liberdade. ${ }^{7}$

Entretanto, não há duvidar que a posição mencionada resta completamente superada, à vista de diplomas normativos internos e internacionais dos quais o Brasil é signatário. $\mathrm{O}$ art. $5^{\circ}$ inciso LVII, da Constituição Federal, consigna o princípio da desconsideração prévia de culpabilidade, e sob a mesma diretriz, o art. 14, n. 2, do Pacto Internacional de Direitos Civis e Políticos de 1966; o art. $6^{\circ}$, n. 2, da Convenção Europeia sobre Direitos Humanos, e o art. $8^{\circ}$, n. 2, da Convenção Americana sobre os Direitos Humanos, referem-se à presunção de inocência. Por conseguinte, toda prisão que não seja cumprimento de sentença penal condenatória passada em julgado deve ser exclusivamente cautelar, sob pena de representar punição antecipada.

Inequivocamente, pena e custódia preventiva assemelham-se quando analisadas sob a perspectiva da privação de liberdade, porque funcionam ambas como medidas de isolamento do sujeito. É necessário reconhecer, todavia, qualidades exacerbadamente divergentes entre os institutos: enquanto a pena se fundamenta tanto na exigência de justiça, quanto em sua respectiva utilidade, ${ }^{8}$ a custódia cautelar, por outro lado, constitui instrumento imprescindível para o próprio processo.

5 Em discordância ao posicionamento acerca do isolamento do imputado com o fim de constituir verdadeira punição antecipada, e em constatação da ampla gama de autores defensores da tese, Francesco Carnelutti assim consignou: "La custodia preventiva ha dunque veramente, secondo la mens legis, il valore di uma espiazione antecipada (...) L'etica dell' esecuzione penale antecipata è quella barbarica, che un poeta ha espresso in un verso famoso: pur chi Il reo non si salvi Il giusto pera" (CARNELUTTI, Francesco. Principi del processo penale. Nápoles: Morano, 1961. p. 181). PISAPIA, Gian Domenico. Compendio di procedura penale. Pádua: Cedam, 1988. p. 258.

Id. Ibid., p. 259.

Magalhães Noronha assevera que o estudo das penas, no que respeita aos seus fundamentos e fins, foi desenvolvido por três grupos que compreendem as teorias absolutas, as relativas e as mistas (NORONHA, 
Os institutos também não apresentam homogeneidade, ainda, quanto aos seus escopos. A pena cumpre não apenas o interesse coletivo quando analisados os aspectos da prevenção geral e específica - expressos respectivamente pelo caráter de exemplaridade da medida e pelo afastamento do imputado do meio social - como também pode ter o caráter individual de reeducar o delinqüente. ${ }^{9}$ Diversamente daquela, a medida cautelar tem escopo único e não objetiva emendar o réu, retribuir um mal, nem eliminar juridicamente o crime. ${ }^{10}$ Assim se fala que a prisão preventiva, tal e qual as outras modalidades de prisão provisória, é fundada em necessidade instrumental, e, portanto, medida meramente cautelar.

Impossível deixar de atentar, no entanto, que a custódia significa risco para o sujeito de direitos, diante da possibilidade de um inocente vir a ser encarcerado no curso do processo por meio de juízo de probabilidade. Por sua vez, também o Estado pode se deparar com a impossibilidade de impor a cautela contra o imputado que, apesar de substanciais indícios de culpabilidade e autoria, não preencher qualquer das condicionantes legais.

Constatada a existência desta verdadeira encruzilhada entre a liberdade e a necessidade da medida, parte da doutrina filiou-se à tendência de oferecer amplamente ao magistrado a possibilidade de optar pela oportunidade da custódia. " Mas esta discricionariedade carece inegavelmente de fundamentos precisos e caracteriza-se pela subjetividade dos pressupostos cautelares, resultando, com frequência, em mecanismo de defesa social. Da ausência de critérios rígidos de qualificação decorrem atenuações da

Edgard Magalhães. Direito penal: introdução parte geral. 10. ed. São Paulo: Saraiva, 1973. v. I, p. 211).

- A Constituição Federal de 1988 não declarou expressamente em seu texto o escopo reeducativo da pena, ao contrário da Carta italiana de 1948, que dispôs no art. 27: "Le pene non possono consistere in trattamenti contrari al senso di umanità e devono tendere alla rieducazione del condannato" Sobre os conceitos de reeducação e reintegração do apenado, importante atentar às valiosas críticas da Criminologia que evidenciam a falsidade destes propósitos no Direito Penal (vide SHECAIRA, S. S. Criminologia. São Paulo: Revista dos Tribunais, 2004; BARATTA, A. Criminologia critica e critica do direito penal, introdução à sociologia do direito penal. Rio de Janeiro: Freitas Bastos, 1999).

10 Contrariamente ao ensinamento de Carlo Umberto Del Pozzo (op. cit, p. 42), não entendemos que a única distinção entre custódia preventiva e pena seja concernente à diversidade de escopos entre ambos os institutos. Malgrado o argumento seja oportuno, não há ignorar que a mais relevante diferença consiste na evidente natureza jurídica antagônica dos institutos, uma vez que a cautela processual de nenhuma maneira pode representar retribuição ou privação de bens jurídicos. O autor aponta uma identificação substancial entre os institutos quando nos parece mais adequado sublinhar as diversidades entre ambos e evitar eventuais equiparações que dilatem o âmbito de atuação das medidas cautelares.

1 "In sè e per sè l'insituto può fare del grande bene o del grande male. La verità, anche se lapalissiana, è che ancora una volta l'elemento decisivo risiede nell 'uomo. Magistrati prudenti, cauti, sensibili e nello stesso tempo coraraggiosi, potrano operare con l'arma che la legge pone nelle loro mani un grande, anche se misconosciuto, bene; mentre giudice disattenti, insensibili, potranno seminare un gran male. Sotto questo profilo, e sotto questo soltanto, è auspicabile che i potere che l'ordinmento processuale vigente attribuisce all'instrutore ed al P.M., in tema de custodia preventiva, pur ridotti dalla legge 18 giugno $1955, n .517$, siano più attentamente ridimensionati" (C. U. Del Pozzo. op. cit, p. 64). 
estrita legalidade e estrita jurisdicionalidade - relativização que alcança a arbitrariedade dos sistemas inquisitivos.

\subsection{Pressupostos do provimento cautelar: Fumus boni juris e Periculum in mora}

Conceitua-se neste item, especificamente, a relação entre os dois pressupostos estudados e a prisão preventiva. Inegável a relevância deste binômio no estudo das medidas cautelares, posto que, os conceitos do fumus boni iuris e do periculum in mora são instrumentos hábeis, em maior ou menor medida, a uma avaliação da conveniência e da necessidade de todas as prisões provisórias existentes no sistema pátrio.

João Mendes Almeida Júnior, ao constatar que "o delito supõe o delinquente" classifica as fases do espírito do juiz diante do fato do delito: em primeiro lugar, a ignorância; em segundo, a dúvida; em terceiro, a suspeita; em quarto, a opinião, e em quinto, a certeza. ${ }^{12} \mathrm{O}$ ensinamento do autor faz-se importante para a compreensão de uma das dimensões necessárias à decretação da medida cautelar, usualmente analisada pela doutrina sob a denominação de pressupostos processuais.

A imposição de medida cautelar não poderá ser realizada se em desfavor do investigado não existirem provas da existência do crime, indícios suficientes de autoria e a probabilidade da ocorrência de um dano. São estes aspectos que viabilizarão ao juiz superar o momento que Almeida Júnior denomina de dúvida, para alcançar o estágio de suspeita em relação ao investigado.

É bem verdade que o magistrado, ao decretar a prisão provisória, não está se posicionando quanto ao cometimento do delito por parte do agente; ou seja, não emite propriamente juízo sobre o fato investigado que expresse opinião ou certeza. Inclusive, se assim o fizer, estará incorrendo em prejulgamento que transborda os limites de sua função jurisdicional e configura flagrante ilegalidade, posto que, a sentença advirá tão somente no decurso do devido processo legal. Por outro lado, atente-se que o status de ignorância ou de dúvida, em relação à existência e autoria do ato antijurídico, não são etapas do convencimento do magistrado compatíveis com a decretação de uma medida tão gravosa quanto a prisão provisória.

A suspeita de que tratamos não é contrária ao princípio da presunção de inocência - verdadeira norma de orientação judiciária e legislativa na interpretação e aplicação das leis. Não se trata da imputação de um delito ao investigado, mas tão somente, da aferição de indícios que apontem um possível responsável pela conduta; são estes elementos mínimos os alicerces da motivação judicial e as bases para que o mandado

12 ALMEIDA JÚNIOR, João Mendes. O processo criminal brasileiro. 4. ed. São Paulo: Freitas Bastos, 1959. p. 346. 
de prisão não esteja ancorado no campo subjetivo da dúvida. Nesse sentido, inoportuna qualquer consideração de que a suspeita subverte o critério do favor rei. ${ }^{13}$

Para a caracterização de suspeita consentânea com a excepcionalidade das medidas restritivas, impreterível, primeiramente, a presença do chamado fumus boni iuris, que na perspectiva do processo penal é costumeiramente previsto como fumus delicti comissi. Desse modo, o juiz haverá de demonstrar por meio de argumento objetivo e concreto quais os elementos presentes nos autos que revelam a existência de crime, bem como o nexo entre este e a participação do agente. A materialidade e a autoria delitiva são critérios a ser explicitados pelo magistrado, de forma que, quanto mais restritiva for a medida, maior deverá ser a convicção judicial. Portanto, a aplicação da mais gravosa das medidas cautelares não poderá se pautar em simples presunções ou conjecturas, mas unicamente em um alto grau de probabilidade. ${ }^{14}$

Por outro lado, temos o denominado periculum in mora, também conceituado na processualística penal como periculum libertatis. O conceito filia-se à probabilidade de um perigo concreto de insatisfação de um direito, em face da demora na prestação jurisdicional definitiva. $^{15}$

A situação de ameaça configurada pelo periculum libertatis, quando envolver algum dos casos expressos no art. 312, do Código de Processo Penal, constitui um dos pressupostos para a decretação da custódia preventiva.

Destarte, as garantias da ordem econômica e da ordem pública estarão em perigo quando o réu - em liberdade - possa concluir crime interrompido ou praticar outros delitos; pensando-se sempre na repercussão danosa e prejudicial ao meio social. Nessa circunstância, em específico, preocupam os possíveis danos que a liberdade do réu possa causar. Na hipótese de conveniência da instrução criminal, o periculum libertatis restará concretizado diante da não apresentação do investigado para que seja interrogado ou para evitar prejuízo decorrente do risco da ocultação de provas, bem como, de possíveis práticas de suborno, corrupção ou coação de vítimas, testemunhas ou peritos. Igualmente relevante é o aspecto do asseguramento da aplicação da lei penal naquelas circunstâncias

13 Maurício Zanóide de Moraes assevera que o "in dubio pro reo traz em si a idéia de que há "dúvida" ("in dubio") e de que esta deve ser resolvida favoravelmente ao réu ("pro reo"). "Favor rei, por sua vez, é uma escolha valorativa que não tem como causa a "dúvida": a base informadora são os ideais de igualdade, dignidade da pessoa humana e proteção da liberdade e do patrimônio do cidadão, por meio de um devido processo legal" (MORAES, Maurício Zanóide de. Presunção de inocência no processo penal brasileiro: análise de sua estrutura normativa para a elaboração legislativa e para a decisão judicial. 2008. Tese (Doutorado) - Faculdade de Direito, Universidade de São Paulo, São Paulo. p. 399).

14 MORAES, Maurício Zanóide de. Presunção de inocência no processo penal brasileiro: análise de sua estrutura normativa para a elaboração legislativa e para a decisão judicial. 2008. Tese (Doutorado) Faculdade de Direito, Universidade de São Paulo, São Paulo. p. 409.

is GRINOVER, A. P.; FERNANDES, A. S.; GOMES FILHO, A. M. As nulidades no processo penal. 10. ed. São Paulo: Revista dos Tribunais, 2007. p 332. 
em que o agente revela o intuito de fuga ao desfazer-se de bens, demonstrando a intenção de empreender viagem ou de ocultação.

\section{Prisão Preventiva e Ordem Pública}

\subsection{Limites da Prisão Preventiva}

A superação do sistema vigente à época da edição do Código de Processo Penal de 1941, que previa a prisão preventiva obrigatória, representou significativa alteração nos rumos da persecução penal. Todavia, ainda hodiernamente observamos que a decretação das prisões provisórias - mesmo não se submetendo a um vínculo apriorístico de coerção previsto pelo legislador - em muitos casos segue verdadeiro automatismo por parte do magistrado.

A imediatez deste raciocínio, costumeiramente baseado em variados fundamentos materiais, tais como a periculosidade do agente e sua vida pregressa; a gravidade do delito e a repercussão social do injusto, faz crer que a esperada tutela dos valores constitucionais ainda está permeada de obstáculos.

Nesse contexto, indissociável da análise de qualquer medida de coerção, o respectivo exame dos limites aos quais deverá estar jungida. O reconhecimento da delimitação e do modo de valoração da oportunidade das medidas limitativas da liberdade pessoal obsta eventuais arbitrariedades judiciais e instaura nexo de legalidade a legitimar a atuação estatal. ${ }^{16}$

No estudo dos limites da prisão provisória, Antonio Scarance Fernandes propõe diferenciação sob os aspectos objetivos, subjetivos e temporais. ${ }^{17}$ Formulação que, por sua razão clareza e adequação é também adotada neste trabalho.

Em atenção ao parâmetro objetivo, importa averiguar primeiramente a natureza do crime e se configurada situação de cautelaridade prevista em lei. Deve tratar-se necessariamente de crime doloso apenado com reclusão, não permitida prisão preventiva nos delitos culposos, nas contravenções penais e nos crimes dolosos punidos com detenção. Entretanto, há que se referir ao inciso III, do art. 313, do Código de Processo Penal, que considera aspectos subjetivos do agente, ao permitir a prisão processual nos casos de dúvida acerca de sua identidade ou quando este não oferecer elementos para esclarecê-la (limite subjetivo relativo ao investigado que será tratado em seguida). Ademais, cumpre

16 CHIAVARIO, Mario. Processo e garanzie della persona. 2. ed. Milão: Giuffrè, 1982. v. 2, p. 268.

17 FERNANDES, Antonio Scarance. Funções e limites da prisão processual. Revista Brasileira de Ciências Criminais, São Paulo, n. 64, 2007. p. 245. 
observar que as prisões cautelares permitidas em Lei são aquelas do art. 312, do estatuto processual. $^{18}$

A adequação da prisão processual depende necessariamente da sujeição do investigado à imposição de pena privativa de liberdade caso condenado; ou seja, a medida será desarrazoada se ao crime investigado for cominada apenas sanção restritiva de direito ou de multa. Da mesma forma, será inviável a prisão do agente se após a condenação a penalidade for suspensa ou houver a possibilidade de vir aplicada em regime aberto - nos casos em que o individuo trabalha ou exerce atividade fora do estabelecimento prisional.

Ainda sob a perspectiva de limitação material, evidente que já escoado no regime de custódia provisória, o tempo da pena a ser aplicada, deverá a pessoa livrarse durante a tramitação de recurso, mesmo porque, inexiste qualquer possibilidade de agravamento da pena pelo tribunal. ${ }^{19}$

Os limites subjetivos, por sua vez, delimitam a atuação dos sujeitos processuais envolvidos na prisão provisória: o juiz, o acusado ou investigado e o Ministério Publico.

Caberá ao juiz decretar a prisão preventiva por meio de ordem fundamentada no inicio da persecução penal (inquérito policial) ou durante a instrução criminal - nos exatos termos do art. $5^{\circ}$, inciso LXI da Constituição Federal. O decreto será abusivo se não respeitar os casos previstos na lei ou se evidenciar a utilização de argumento legal para encobertar outra motivação. Portanto, a mera repetição da motivação legal nos autos, desprovida de suportes fáticos e eivada de hipóteses e suposições, claramente extrapola os limites da atuação fidedigna do magistrado.

O Ministério Público, órgão incumbido de zelar pelas instituições democráticas, está legitimado a requerer a custódia cautelar. A medida também poderá ser decretada de ofício pelo magistrado; mediante requerimento do querelante ou por representação da autoridade policial.Alega-se, contudo, que a prisão preventiva, sem anterior manifestação do órgão público acusador, pode representar desvantagem para o indiciado. ${ }^{20}$

18 Se do exame das provas dos autos o juiz constatar uma das hipóteses dos arts. 23 a 25 , do Código Penal, tal como exposto no art. 314, do Código de Processo Penal, a prisão preventiva não será decretada. Evidente que nesta circunstancia não se exige plena prova de exclusão do crime a ponto de delinear-se verdadeira absolvição do delito (SZNICK, Valdir. Liberdade, prisão cautelar e temporária. 2. ed. São Paulo: EUD, 1995. p.456).

19 Antonio Scarance Fernandes sugere que também nas hipóteses de regime semi-aberto não se deveria manter ou determinar a prisão processual, porque nesse caso é possível inferir que o magistrado, após o exame das circunstâncias do art. 59 do Código Penal, concluiu que eram favoráveis ao acusado; ponderação que não se coaduna com a imposição da prisão (op. cit., p. 247).

20 A prisão de oficio poderia revelar uma propensão do juiz de julgar em sentido contrário a pessoa investigada, nesse sentido FERNANDES, Antonio Scarance. Funções e limites da prisão processual. Revista Brasileira de Ciências Criminais, São Paulo, n. 64, 2007. p. 248. 
No âmbito também dos aspectos objetivos e subjetivos, ainda outra limitação - de ordem temporal - deve ser conhecida. Em matéria de restrição de direitos individuais, não há perder de vista que nenhuma medida poderá vir perpetuada além do lapso temporal estritamente necessário, sob pena de vilipêndio à proporcionalidade da atuação estatal no tratamento da pessoa, com o risco de arbitrariedades.

Constantemente reafirmado na doutrina e jurisprudência, o marco temporal de oitenta e um dias para a manutenção da prisão preventiva, baseia-se na orientação da injustiça de prisão que exceda a soma do tempo dos atos do procedimento. Entretanto, a regra jurisprudencial mencionada foi paulatinamente mitigada, tolerando-se a manutenção da custódia, embora ultrapassado o prazo legal, em certas circunstâncias: um grande número de réus na mesma ação penal; a complexidade da causa; a necessidade da expedição de precatória e da instauração de incidentes. Leciona Antonio Scarance Fernandes ${ }^{21}$ que a verificação de eventual constrangimento ilegal pelo excesso da prisão passou a ser configurado após o marco inicial dos oitenta e um dias, não persistindo, contudo, orientação para a automática liberação do preso. ${ }^{22}$

\subsection{Requisitos}

\subsubsection{Conveniência da Instrução Penal}

O requisito da conveniência da instrução criminal está diretamente associado ao perigo de insatisfação ou satisfação tardia da tutela de um direito.Para que o decurso do tempo não impeça a efetividade do processo, de rigor sejam adiantadas providências com o escopo de preservar o bom andamento da instrução. Outro aspecto relevante concerne ao interesse de possibilitar o célere fluxo da persecução penal, de forma a assegurar a participação do acusado em todos os atos processuais.

O fundamento ora apresentado dispõe, portanto, de dupla função. Primeiramente, trata-se de coação judicial adstrita às hipóteses em que o suspeito esteja a dificultar a colheita de provas ou mostre-se direcionado a quebrantar a ordem regular do curso das investigações. Indevido será o emprego, nesta hipótese, de asserção genérica sobre a periculosidade do agente, com a presunção de personalidade indicativa de pessoa

21 FERNANDES, Antonio Scarance. Funções e limites da prisão processual. Revista Brasileira de Ciências Criminais, São Paulo, n. 64, 2007. p. 250.

22 Em palestra realizada no salão nobre da Faculdade de Direito da USP, no curso "Reformas do Código de Processo Penal" promovido pelo Departamento XI de Agosto, em outubro de 2008, o Professor Doutor José Raul Gavião de Almeida ressaltou que o prazo de oitenta e um dias da prisão processual é de ser reinterpretado à luz da Reforma do Código de Processo Penal (Leis 11.719/08, 11.689/08 e 11.690/08). Uma vez que a prisão será injusta se exceder a soma do tempo dos atos processuais, em virtude das alterações no curso do procedimento o prazo também deverá ser recalculado pelos intérpretes do Direito. 
voltada para o crime e interessada na obstrução da persecução simplesmente em razão de análise subjetiva. Sem que a expressão conveniencia da instrução possa autorizar a discricionariedade do julgador, que deverá se ater ao dano infligido pelo investigado ou a uma substancial probabilidade de prejuízo futuro. Enfim, a conduta do investigado deve ser apta a conturbar a produção das provas como, v.g., nos casos de corrupção, suborno ou coação contra vítimas, testemunhas, peritos e servidores da justiça. ${ }^{23}$

Sob um segundo viés, o constrangimento do indiciado objetivará sua participação no processo. Tal presença significará restrição momentânea da liberdade para que esteja presente nos atos processuais e possa manifestar-se na reconstrução fática dos eventos examinados. O próprio aspecto somático também será escopo desta apresentação, que evidentemente facilita o reconhecimento da identidade do investigado.

A prisão baseada nesta motivação não poderá perdurar além da fase instrutória. Tão logo se mostre dispensável a continuidade da medida, ausente o requisito legal, deverá ser imediatamente revogada.Ademais, possível aduzir que este requisito não ensejará prazo de coerção muito alongado quando alicerçado apenas na intenção de constranger o indiciado a comparecer a algum ato processual específico. Sob outro prisma, mais acentuado será o tempo de detenção se a fundamentação disser respeito a ameaças contra certas pessoas, posto que o risco das perseguições poderá persistir até o término da instrução.

Não nos parece adequado o argumento por vezes exposto na doutrina de que a prisão para a conveniência da instrução penal pode acessoriamente favorecer a autodefesa do investigado, a reforçar "o contraditório real e indisponível" ${ }^{24}$ Ora, é indubitável que o status de liberdade é aquele que melhor oferece condições para a pessoa formular todo o plexo de argumentos em favor de sua inocência. Não se quer aqui defender a legitimidade da permanência em liberdade quando regular a decretação da prisão preventiva com base neste requisito, mas apenas constatar que qualquer oportunidade de autodefesa oferecida pela prisão é consequência mediata e em nada tem relação com os objetivos da custódia provisória. O simples fato de aceitar-se esta decorrência secundária como positiva representa engano perigoso, especialmente para o magistrado, já que poderá influenciá-lo subjetivamente, levando-o a crer não ser a medida de todo o mal ao indiciado, que terá oportunidade para se defender.

BARROS, R. P. Campos. op. cit., p. 201.

24 PITOMBO, S. M. M. Prisão preventiva em sentido estrito. In: PENTEADO, Jacques de Camargo (Coord.). Justiça Penal, n.7. São Paulo: Revista dos Tribunais, 2000. p. 129. 


\subsubsection{Garantia da aplicação da lei penal}

A garantia da aplicação da lei penal, a exemplo da conveniência da instrução processual, trata-se de medida acautelatória, diante do risco do periculum in mora. Não se almeja antecipar os efeitos da pena, mas sim, assegurar a futura realização de uma eventual execução criminal.

O perigo de fuga é evento hábil a tornar ilusória a condenação. Desse modo, à medida que o indiciado começa a se desfazer de imóveis para deixar seu domicílio ou revela o desejo de empreender viagem, acentuado será o risco da inexecução de uma futura pena. Tanto a fuga quanto o perigo de fuga - revolta contra o exercício do poder estatal e circunstância preparatória desta rebelião, respectivamente - legitimam a decretação da medida cautelar porque evitam o indesejado comprometimento da marcha processual e a consequente impunidade do agente.

A aferição do perigo de evasão sujeitar-se-á ao exame de circunstâncias concretas. Para tanto, imprescindível avaliar a permanência do inculpado em sua residência habitual, bem como a manutenção da aparência de habitualidade no exercício de suas funções regulares, como trabalho e negócios. Falsa informação sobre seu domicílio e um comportamento desidioso - em nada propenso a favorecer o processo - são critérios que avaliados cumulativamente, respeitada a proporcionalidade, ensejarão a decretação da prisão preventiva do agente. ${ }^{25}$

\subsubsection{Garantia da Ordem Econômica}

A Lei n. 8.884, de 11 de junho de 1994, incluiu o preceito, modificando a redação do art. 312, do Código de Processo Penal.A regra legal corresponde a um desdobramento do conceito de garantia da ordem pública.

O legislador, ao introduzir a preservação da ordem econômica, atentou aos crimes que envolvem grandes golpes no mercado financeiro, delitos praticados normalmente sem o uso da violência física, valendo-se o agente da inteligência e do engodo. Aparentemente, a criminalidade econômica, frequente nos altos escalões governamentais e no mercado financeiro, não atinge diretamente o cidadão se comparada aos efeitos da delinquência violenta. Inegável, no entanto, que as conseqüências dessa criminalidade são por vezes nefastas e atingem grande número de indivíduos. ${ }^{26}$

\footnotetext{
25 ROMERO, Cecilia Sanchez. La prisión preventiva en un estado de derecho. Revista de la Asociación de Ciências Penules de Costa Rica, São José, ano IX, n. 14, 1997. p. 61.

26 DELMANTO JUNIOR, R. As modalidades de prisão provisória e seu prazo de duração. 2. ed. Rio de Janeiro: Renovar, 2001 p. 191-192.
} 
Segundo a Lei 8.884, de 11 de junho de 1994, o inculpado, ao dar causa a grave abalo à situação econômica de uma instituição financeira ou órgão do Estado, passa a receber o mesmo tratamento dos réus ou investigados por outros crimes, A exemplo do que se argumenta em razão da procedência da prisão fundada na ordem pública, também neste caso se leva em conta a gravidade do delito e sua repercussão social; daí se falar também que a magnitude da lesão causa repugnância ao corpo social. ${ }^{27}$

Algumas hipóteses de prisão preventiva lastreadas nesse requisito estão no art. $4^{\circ}$, incisos IV e VII, da Lei n. 8.137, de 27 de dezembro de 1990, que correspondem, respectivamente, ao comerciante que: “(...) açambarcar, sonegar, destruir ou inutilizar bens de produção ou de consumo, com o fim de estabelecer monopólio ou de eliminar, total ou parcialmente, a concorrência" (inciso IV), ou que "elevar, sem justa causa, o preço de bem ou serviço, valendo-se de posição dominante no mercado" (inciso VII, na redação da Lei n. 8.884/94). Das condutas previstas no art. 21, da Lei n. 8.884, de 11 de junho de 1994, que dispõe sobre a prevenção e a repressão às infrações contra a ordem econômica, poderá decorrer prisão quando configurada a hipótese do art. 20 e incisos. ${ }^{28}$

\subsubsection{Garantia da Ordem Pública}

A noção de ordem pública - em muitos ordenamentos erigida à categoria de cânone do processo penal - já em 1789 foi utilizada para reconhecer o direito de opinião (art. 10 da Declaração de Direitos do Homem). ${ }^{29}$ A partir de então, por tantas vezes foi reempregada que alcançou status de autêntico referencial para muitos modelos de Estado. ${ }^{30}$

Odone Sanguiné observa que ao tempo das constituições monárquicas a cláusula da ordem pública era recorrente, de sorte que todos os textos constitucionais promulgados na Espanha durante o século XIX - fenômeno corroborado em muitos ordenamentos - invariavelmente empregaram a terminologia. Segundo o autor, o conceito invocado como justificativa das medidas necessárias para assegurar a manutenção da paz pública e a convivência ordenada dos cidadãos dentro dos grupos sociais - cambiando

27 NUCCI, G. S. Código de processo penal comentado. 3. ed. São Paulo: Revista dos Tribunais, 2004. p. 567.

28 Verbis: "Art. 20. Constituem infração da ordem economica, independentemente de culpa, os atos sob qualquer forma manifestados, que tenham por objeto ou possam produzir os seguintes efeitos, ainda que não sejam alcançados: I - limitar, falsear ou de qualquer forma prejudicar a livre concorrència ou livre iniciativa; II - dominar mercado relevante de bens ou serviços; III-aumentar arbitrariamente os lucros; IV-exercer de forma abusiva posição dominante" Exemplos evidenciados por (TOURINHO, Femando da Costa. Manual de processo penal. 9. ed. São Paulo: Saraiva, 2007. p. 626-627), Julio Fabbrini Mirabete ainda menciona outras duas leis: 7.492/86 e 1.521./52 (MIRABETE, Julio Fabbrini. Processo penal. 16. ed. São Paulo: Atlas, 2004. p. 418).

29 "Article 10. Nul ne doitêtre inquiété pour ses opinions, même religieuses, pourvu que leurmanifestation ne trouble pas l'ordre établi par la loi.

30 Sobre as funções desta terminologia no discurso do Estado de direitos, FARIA, J. E. Campos de Oliveira. Retórica política e ideologia democrática. São Paulo: Tese, 1982. p. 43. 
apenas a intensidade com que aplicado -, permanece na ordem do dia no século XX, tanto para as ditaduras como para os regimes democráticos liberais. ${ }^{31}$

Entre nós, a noção de ordem pública, incorporada ao Processo Penal pátrio sob a égide da Constituição de 1937, vem atualmente estabelecida no art. 312, do estatuto. Nas sistematizações alienígenas é possível notar que ora é empregada e ora substituída, não mais refletindo o consenso na sua utilização. Nem sendo encontrada nos sistemas hodiernos da Inglaterra, Itália e Alemanha (neste último, suprimida desde o ano de 1945). Por sua vez, Bélgica e Espanha, ${ }^{32}$ com noções próximas, admitem a prisão provisória, respectivamente, nos casos de "absoluta necessidade para a segurança pública" e de "inquietude provocada na população" 33

Inquestionável, pois, a recorrência da ordem pública desde o advento da Carta de Direitos de 1789 até os dias atuais.

Destas observações iniciais há que passar ao estudo semântico do termo. Se analisarmos especificamente o vocábulo ordem encontraremos uma constante modulação entre aquilo que vai ser e aquilo que deve ser. Trata-se de arranjo que segue determinada metodologia; ajuste de uma circunstância a certas condições previamente estabelecidas sem as quais se caracteriza a desordem. Daí se afirma que a ordem compreende não apenas a realidade como ela é, mas também a indicação de como a realidade deve ser. A ordem está sempre constituída por certa disposição dos elementos, em que cada qual apresenta lugar no conjunto e para que assim se possa formar uma unidade. ${ }^{34}$

A ordem pública, por seu turno, constitui o status quo de circunstâncias da vida que representem a normalidade da coletividade de uma dada sociedade (tranquilidade e paz social que permitam o desenvolvimento das relações sociais e econômicas). Há que se pensar, pois, na habitualidade de comportamentos e eventos, para se vislumbrar, por via inversa, as situações aptas à caracterização de anomalias ou de condições perturbadoras. Este conjunto de condições é sensível ao momento histórico em que se encontre, por isso, cambiável diante das classes socialmente dominantes em um dado momento.

Se por um lado a ordem pública pode ser entendida como convivência segura, pacífica e ordenada, pode-se prosseguir nesta conceituação compreendendo-a, pois, como próprio reflexo do anseio social de justiça. O legislador emprega o termo com vistas à preservação de certos valores fundamentais e na preocupação de assegurar um

31 SANGUINÉ, Odone. Prisión provisional y derechos fundamentales. Tirant: Valência, 2003. p. 171.

32 LOPES JUNIOR, A. C. Medidas cautelares no direito processual penal espanhol, medidas cautelares no direito processual penal espanhol. Revista da Associação dos Juizes do Rio Grande do Sul, Porto Alegre, ano XXIV, n. 69, 1997. p. 151-153.

33 Na França o conceito nunca chegou a ser suprimido. Atualmente, com o advento da Lei de 30 de dezembro de 1996, propõe-se uma utilização mais parcimoniosa e excepcional deste requisito como fundamento para a prisão provisória (GUÉRY, C. Détencion provisoire. Paris: Dalloz, 2001, p. 32).

34 BECHARA, F. R. Prisão cautelar. São Paulo: Malheiros, 2005. p. 94. 
ambiente favorável ao desenvolvimento humano - ínsita na referência à garantia da ordem pública, a ideia de tutela dos direitos do povo (obediência às leis; respeito às pessoas, à propriedade...).

O conceito ocupa lugar de standard jurídico. A exemplo de formulações como "o melhor interesse da criança" "os bons costumes" e o bonus paterfamilias, caracterizase como noção indeterminada que busca estabelecer um padrão de normalidade, reflexo da tentativa de atribuir normatividade jurídica a critérios técnicos ou sociais.

Justamente por se tratar de standard jurídico, a ordem pública é conceito conhecido em diversos ramos do Direito (v.g., no Direito Administrativo e no Direito Civil).No Processo Penal, inegável a relevância do conceito, porquanto, pela redação do art. 312, do Código pátrio, trata-se de um dos requisitos da prisão preventiva.

Christian Guéry, na tentativa de restringir a indeterminação do termo na seara do Processo Penal, recorreu à análise de Faustin-Hélie, interpretando a ordre public como a necessidade de por fim a uma desordem; emoção causada diante de qualquer crime violento e abominável; necessidade de proteger a coletividade das repercussões imediatas e excessivas da multidão efervescente; necessidade de proteger outras eventuais vítimas futuras; evitar a reiteração da infração e proteger o autor. ${ }^{35}$

$\mathrm{O}$ doutrinador aponta como imprescindível à configuração de ameaça à ordem pública, a presença de distúrbio concreto, de modo que o desarranjo e a emoção sejam reais e objetivos. Todavia, adverte Guéry, ainda se emprega erroneamente o conceito como sinônimo de gravidade dos fatos e da impressão que esta gravidade possa causar sobre a população. Ademais, é deixado de valorar se o distúrbio observado cessaria com a prisão do réu ou indiciado - pois, em caso contrário, a prisão não satisfaria o ideal de garantia da ordem. ${ }^{36}$

\subsection{A garantia da ordem pública na jurisprudência}

À medida que oferece grande margem de discricionariedade ao juiz, não é de ignorar que todo standard jurídico necessita de apreciação concreta. $\mathrm{Na}$ interpretação da prisão preventiva, o Supremo Tribunal Federal, nos últimos quinze anos, consolidou tratar-se de medida excepcional, como depreendido de voto proferido pelo Relator Ministro Marco Aurélio no julgamento do Habeas Corpus n. 71.361:

Não há como inverter a ordem natural das coisas, tal como definida pelo ordenamento jurídico, elegendo-se a possibilidade de responder em liberdade a acusação, simples acusação, em exceção. Enquanto ciência, em direito, o meio

35 Apud, GUÉRY, C. Détencion provisoire. Dalloz: Paris, 2001. p. 31.

36 Id. Ibid., p. 32. 
justifica o fim, mas não este aquele, mormente quando se parte da visão distorcida sobre constituir-se a postura rigorosa em panacéia para consertar o quadro de delinqüência notado." 37

A Magna Corte, à luz da presunção de inocência, sustenta pela maioria de seus membros que a prisão anterior ao trânsito em julgado da sentença condenatória não pode ter caráter de pena e deve sempre estar fundamentada na cautelaridade. ${ }^{38}$ Indispensável, destarte, a diferenciação entre prisão penal e prisão preventiva, à medida que esta última visa atuar em benefício da atividade estatal desenvolvida no processo penal: ${ }^{39}$

(...) a prisão preventiva só se admite na medida em que necessária para resguardar a lisura da instrução do processo, a aplicação da lei penal, na eventualidade da condenação e, em termos, a ordem pública; e a aferição, em cada caso, da necessidade da prisão preventiva há de partir de fatos concretos, não de temores ou suposições abstratas. Inidoneidade, no caso, da motivaçãoda necessidade da prisão preventiva, que, despida de qualquer base empírica e concreta, busca amparar-se em juízos subjetivos de valor acerca do poder de intimidação de um dos acusados e menções difusas a antecedentes de violência, que nenhum deles se identifica. ${ }^{40}$

Enfim, para a Excelsa Corte, a gravidade do crime imputado não basta à justificação da prisão preventiva. ${ }^{41}$ Indispensável a presença de base factual a demonstrar a necessidade da medida, ${ }^{42}$ bem como sua duração limitada, observado o prazo regular do processo. ${ }^{43}$

Nada obstante a diretriz da excepcionalidade da prisão cautelar firmada no Pretório Excelso, no estudo da jurisprudência dos Tribunais pátrios é possível identificar

\footnotetext{
Segunda Turma, j. 23.09.1994.

38 RCL-MC n. 2.391, DJ 16.05.2008, Rel.Min. Marco Aurélio.

39 HC n. 79.857, Segunda Turma, j. 04.05.2001, Rel.Min.Celso de Mello. No mesmo sentido, $\mathrm{HC}$ n ${ }^{\circ} 86.620$, Primeira Turma, DJ 17.02.2006, Rel. Min. Eros Grau; HC n. 89.501, Segunda Turma, DJ 16.03.2007, Rel. Min. Celso de Mello.

40 RHC n. 83.179, Pleno, j. 22.08.2003, Rel. Min. Sepúlveda Pertence.

41 RHC n. 68.631, Rel. Min. Sepúlveda Pertence, in RTJ 137/287; HC n. 69.950, Min. Francisco Rezek, in RTJ 128/147; HC n. 79.204, Rel. Min. Sepúlveda Pertence; HC n. 84. 884, Rel. Min. Sepúlveda Pertence; HC n. 85.036, Rel. Min. Eros Grau; HC n. 85.900, Rel. Min. Sepúlveda Pertence; HC n. 84.797-MC,Rel. Min. Cezar Peluso.

42 HC n. 87.343-MC, DJ 01.02.2006, Rel. Min.Cezar Peluso. A decretação da prisão preventiva para preservar a credibilidade da Justiça não é aceita no Supremo Tribunal Federal ( HC n. 82.797-7/PR; HC n. 80.719-4/ $\mathrm{SP})$.

43 HC n. 87.913, Primeira Turma, j. 07.12.2006, Rel. Min. Cármen Lúcia; HC n. 86.104, Primeira Turma, j. 23.03.2007, Rel. Min. Marco Aurélio; HC n. 85.237, j. 17.03.2005, Rel. Min. Celso de Mello; HC n. 85.583/ MG, Primeira Turma, j. 08.08.2005, Rel. Min. Sepúlveda Pertence.
} 
decretos de custódia preventiva que, fundados na garantia da ordem pública, aludem a aspectos relacionados ao delito, ao agente ou ao processo. $\mathrm{O}$ caráter hediondo do crime perpetrado, ${ }^{44}$ por si só, capaz de ensejar restrições à liberdade individual. Também, o imenso clamor público ${ }^{45}$ gerado pela conduta do agente; a expectativa de que, ao se livrar solto, possa dar continuidade à prática delitiva ou reiterar a ação criminosa; ${ }^{46}$ a impossibilidade de garantir-se-lhe a integridade física fora do cárcere; ${ }^{47}$ e a periculosidade revelada por seu comportamento pregresso. ${ }^{48}$

Ainda mencionadas a prevenção da violência, através da intimidação do criminoso e da manutenção da credibilidade do Poder Judiciário, ${ }^{49}$ que restaria comprometida caso permanecesse ele fora do cárcere. Mesmo nas situações em que a soltura do agente representa ameaça à vítima e às testemunhas, com frequência determinante da prisão preventiva por conveniência da instrução criminal, motiva-se com supedâneo na garantia da ordem pública; da mesma forma, por vezes, no que respeita ao fundamento da garantia do cumprimento de eventual sentença condenatória ao balizamento da questão pela Suprema Corte ao longo destes quinze anos, ainda não se deu repercussão suficiente que permita concluir concretamente restrita a hipóteses excepcionais a garantia da ordem pública. Lamentável o dissídio jurisprudencial sobre o tema, baralhadas as interpretações do conceito.

\section{Direitos Fundamentais e Ordem Pública}

A interpretação dos direitos fundamentais varia ao longo da história. Cada ordenamento jurídico traduz a imagem do homem assente em uma determinada época e local. A proteção dos direitos fundamentais inscritos na normativa constitucional reflete bem a noção de homem prestigiada pelo legislador. O tríptico liberdade, igualdade e fraternidade, que em 1789 inspirou os revolucionários franceses, continua a infundir-

44 STJ, RHC n.25.868/MT, Quinta Turma, j. 23.06.2009, Rel. Min. Arnaldo Esteves Lima; TRF-1, HC n. 2002.01.00.007333-6/TO, QuartaTurma, j..28.05.2002.

45 TRF-2, HC n. 5.516, Primeira Turma, j. 23.07.2008; TJSP, HC n. 990091256439, 7ª Câmara, j. 30.07.2009.

46 STJ, HC n. 118.599/ PR, Quinta Turma, j. 23.06.2009, Rel. Min. Jorge Mussi; STJ, HC n. 104.610/RJ, Quinta Turma, j. 18.06.2009, Rel. Min. Laurita Vaz; HC n. 125.362/AM, Quinta Turma, j. 18.06.2009, Rel. Min. Napoleão Nunes Maia Filho; TRF-2, HC n. 6.352, Primeira Turma, j. 10.06.2009.

47 STF, RHC 60.973, Segunda Turma, j. 27.05.1983, Rel. Min. Francisco Rezek; TRF1, HC 2003.01.00.0000324/RR, Terceira Turma, j. 11.03.2003.

48 STJ, HC n. 120.108/ES, Sexta Turma, j. 23.06.2009, Rel. Min. Jane Silva; STJ, HC n. 124.539/ RS, Sexta Turma, j. 18.06.2009, Rel. Min. OG Fernandes; HC n. 130.987/ BA, Quinta Turma, j. 18.06.2009, Rel. Min. Arnaldo Esteves Lima; TRF-2, HC n. 6.327, Segunda Turma, j. 26.05.2009.

49 STJ, HC n. 123.923/CE, Quinta Turma, j. 04.06.2009, Rel. Min. Napoleão Nunes Maia Filho; TRF-2, HC n.6.050, Segunda Turma, j. 04.11.2008; TRF-2, HC n.5.401, Segunda Turma,j. 13.11.2007; TRF-1, HC n. 2006.01.00.027668-0/PA, Quarta Turma, j. 23.10.2006; TRF-1, HC n. 2006.01.00.023114-0/AC, Quarta Turma, j. 08.08.2006. 
se nas legislações contemporâneas. Se os mesmos direitos fundamentais podem ser identificados em distintos momentos históricos, a maneira de interpretá-los, contudo, modifica-se continuamente.

No Processo Penal o respeito aos direitos individuais está expresso em um amplo rol de garantias constitucionais, todas oriundas da tradição do due processo of law. Sem prejuízo de outros, há que se destacar: acesso à Justiça Penal (CF, art. $5^{\circ}$, LXXI e LXXVII); juiz natural em matéria penal (CF, art. $5^{\circ}$, XXXVII, XXXVIII e LIII); tratamento paritário dos sujeitos parciais do processo penal (CF, art. $5^{\circ}$, caput); plenitude de defesa do indiciado, acusado ou condenado, com todos os meios e recursos (CF, art. $5^{\circ}$, LV, LVI); contraditório (CF, art5 $\left.{ }^{\circ} \mathrm{LV}\right)$; publicidade dos atos processuais penais (CF, art. $5^{\circ}$, LX, e 93, IX); motivação dos atos decisórios (art. 93, IX); fixação de prazo razoável de duração do processo (CF, art. $\left.5^{\circ} \S 2\right)$; e legalidade da execução penal (CF, art. $5^{\circ}, \mathrm{XLV}$, XLVI, XLVII, XLVIII, XLIX, XL, LXV). ${ }^{50}$

Cientes de todas as garantias do devido processo penal, nesse item discorremos brevemente acerca de quatro princípios particularmente relevantes para a compreensão das prisões provisórias, à luz dos Direitos Fundamentais: legalidade estrita, estrita jurisdicionalidade, presunção de inocência e proporcionalidade.

\subsection{Legalidade estrita e estrita jurisdicionalidade}

A exemplo do preconizado por Luigi Ferrajoli e outros que modernamente defendem os ensinamentos de Beccaria e Carrara, o Processo Penal não se confina à construção de modelo teórico de apuração inexorável de atos típicos, antijurídicos e culpáveis. ${ }^{51}$ Para tanto, não há perder de memória que a razão de ser do Processo Penal, embora meramente subsidiária - porquanto, nunca pretenderá qualquer fim não previsto na Constituição Federal -reside em tornar-se instrumento concreto não apenas apto a cominar punição em desfavor da Pessoa, mas, sobretudo, capaz de tutelar-lhe a liberdade.

Assim, ao reconstituir com o maior grau possível de verossimilhança os eventos ocorridos no passado, o escopo de punição deve estar destinado somente aos

so TUCCI, Rogério Lauria. Direitos e garantias individuais no processo penal brasileiro. 3. ed. São Paulo: Revista dos Tribunais, 2009. p. 61-64.

s1 Ferrajoli propõe o emprego de um sistema formado pela racionalidade e certeza - condicionado e limitado - voltado ao grau máximo de tutela das liberdades dos cidadãos diante do arbítrio punitivo. Desse modo, resulta excluída a responsabilidade penal sempre que estejam incertos ou indeterminados certos pressupostos. Nesse sentido, o autor defende o uso do direito penal mínimo como modus operandi da racionalidade jurídica: o direito penal é mínimo não porque se opte por não punir, mas sim porque a pena somente advirá de procedimento que observe o devido processo legal e onde estejam resguardadas todas as garantias constitucionais (FERRAJOLI, Luigi. Diritto e ragione. Trad. port. de Ana Paula Zomer Sica, Fauzi Hassan Choukr, Juarez Tavares e Luis Flávio Gomes. 2. ed. São Paulo: Revista dos Tribunais, 2006. p. 102). 
crimes que restem suficientemente comprovados, observada a legalidade de todas as etapas do procedimento. ${ }^{52}$

Diante da conjuntura ora afirmada, exsurge crucial o questionamento dos limites que devem ser impostos à discricionariedade legislativa na individuação das situações passíveis de aplicação das medidas restritivas da liberdade pessoal.

$\mathrm{O}$ art. $5^{\circ}$ da Carta Magna, é expresso ao consignar a inviolabilidade do direito à liberdade. Os incisos XLVI a LIV, LXVI e LVIII consagram, por sua vez, o corolário do sacrifício mínimo da liberdade, instituído não apenas sob a égide do princípio interpretativo in dubio pro libertate, mas também imbuído de diretiva vinculante do próprio legislador, para que não constranja, além do imprescindivel, a liberdade pessoal do imputado. Nesse sentido, ainda, o art. $9^{\circ} 1$, do Pacto Internacional sobre Direitos Civis e Políticos; e o art. $7^{\circ}, 2$ e 3, da Convenção Americana sobre Direitos Humanos.

Luigi Ferrajoli, na célebre obra Direito e Razão, associa duas ordens de postulados que compõem parcela representativa dos alicerces da Teoria Garantista: de um lado, convencionalismo penal e legalidade estrita; de outro, o cognitivismo processual e a estrita jurisdicionalidade..$^{53}$

A legalidade estrita pressupõe, primeiramente, o caráter formal ou legal do critério de definição do desvio, que jamais será conhecido na casuística e por meio de características intrínsecas ou ontológicas a indicar aquilo que é socialmente lesivo ou imoral. Na verdade, o princípio consagra o desvio como a expressão da prescrição formalmente definida em lei como pressuposto necessário para a aplicação de uma pena. Dessa maneira é de se falar na submissão do juiz à lei, que atuará em adstrita convergência com a fórmula nulla poena et nullum crimen sine lege.

O mesmo princípio abrange, em um segundo momento, o caráter empírico dos desvios legalmente definidos, que não preconiza referências a figuras subjetivas de status ou de autor, mas apenas figuras empíricas e objetivas de comportamento. Há, pois, a imprescindibilidade das referências empíricas e fáticas precisas e exaustivas, convergentes com a máxima nulla poena sine crimine et sine culpa. ${ }^{54}$

Daí valer-se o autor do termo convencionalismo relacionado à legalidade estrita, haja vista a preocupação da manutenção nominalista e empírica do desvio punível, extirpando-se qualquer configuração extralegal das hipóteses cabíveis. Não se admite sejam criadas situações de desvio sem nada prescrever, cujo conteúdo possa transitar por mais de uma possibilidade de ação - a proibição, enquanto modalidade deôntica, há que

\footnotetext{
52 O sistema de controle penal descrito consagra a vinculação à lei nos planos substancial e processual. Associa-se, com base nestas premissas, à construção de um Direito Penal mínimo.

53 FERRAJOLI, Luigi. Diritto e ragione. Trad. port. de Ana Paula Zomer Sica, Fauzi Hassan Choukr, Juarez Tavares e Luis Flávio Gomes. 2. ed. São Paulo: Revista dos Tribunais, 2006. p. 38-42.

s4 Id. Ibid., p. 38-39.
} 
ser aplicável a todos indistintamente, não podendo se referir a diferenciações políticas, sociais ou antropológicas.

Por sua vez, a estrita jurisdicionalidade, vista pela perspectiva do cognitivismo processual na determinação do desvio punível, concerne às motivações, às razões de fato e de direito acolhidas para sua justificação. É condição indispensável da pena, não somente a lei, mas também a hipótese de acusação que contenha prova, consoante a fórmula nulla poena et nulla culpa sine judicio. Ferrajoli ainda prevê a necessidade de verificações expostas a refutação - apresentadas provas e contraprovas -conforme a máxima nullum judicium sine probatione. ${ }^{55}$

$\mathrm{O}$ autor Mario Chiavario, sob a mesma diretriz de Ferrajoli, alerta que a restrição da liberdade pessoal se faz possível mediante ato motivado da autoridade judiciária, observada a reserva de jurisdição. O autor alerta, todavia, que tal reserva não é absoluta, pois em casos excepcionais, mediante necessidade e urgência, pode-se prescindir, ao menos inicialmente, de ato judicial. Advirta-se que neste caso a derrogação da reserva da jurisdição vem balizada, todavia, pelo reforçamento da reserva da lei, haja vista que a polícia seguirá o procedimento legal em se tratando de prisão em flagrante. ${ }^{56}$

É de se concluir, por conseguinte, que o caput e o inciso LXI, do art. $5^{\circ}$, da Lei Maior, prescrevem a reserva de jurisdição, relativizada tão somente nos casos previstos na própria lei. O inciso LXI, do art. $5^{\circ}$ : da Carta, configura, desse modo, regra de legitimação que investe a autoridade judiciária de competência e exige proceda sempre por ato motivado.

\subsection{Presunção de Inocência}

A Declaração de Direitos do Homem e do Cidadão de 1789 retomou o conceito de presunção de inocência - que apesar de já conhecido dos romanos foi olvidado pelas práticas inquisitórias da Baixa Idade Média --, e assim inscreveu-o no art. $9^{\circ}$ da Carta:

Tout homme étant présumé innocent jusqu'à ce qu'il ait été déclaré coupable, s'il est jugé indispensable de l'arrêter, toute rigueur qui ne serait pas nécessaire pour s'assurer de sa personne doit être sévèrement réprimée par la loi.

s5 FERRAJOLI, Luigi. Diritto e ragione. Trad. port. de Ana Paula Zomer Sica, Fauzi Hassan Choukr, Juarez Tavares e Luis Flávio Gomes. 2. ed. São Paulo: Revista dos Tribunais, 2006. p. 40-41.

56 Mário Chiavario detecta exceção ao princípio da reserva jurisdicional ao examinar o art. 13, da Constituição Italiana; que a exemplo do inc. LXI ,do art. $5^{\circ}$, da Constituição Federal do Brasil, prevê a hipótese da prisão em flagrante (CHIAVARIO, Mário. Libertà personale e processo penale. L'Indice Penale, Pádua, ano XXI, n. 2, 1987. p. 216). 
O texto do artigo pode ser interpretado de duas maneiras diversas. Por um lado, tem-se regra de tratamento do imputado, garantia que impede a adoção de medidas restritivas da liberdade pessoal antes do reconhecimento da culpabilidade, salvo absoluta necessidade. Por outro, depara-se com verdadeira regra de juízo, vez que o acusado não está obrigado a fornecer provas de sua inocência. Toca à acusação o ônus da prova e persistindo dúvida quanto à materialidade ou autoria do delito, o inculpado deverá ser absolvido.

A trajetória do princípio da presunção de inocência permeia toda a evolução do debate acerca da prisão provisória. Para os clássicos, em estudos nos meados do século XIX, a inocência é compreendida como pressuposto da ciência penal e modelo de consecução do justo processo. Carrara conceitua a conveniência da prisão preventiva jungida às necessidades do processo e por tempo brevíssimo, apenas para a realização da apresentação e interrogatório do réu. ${ }^{57}$

O autor aponta o hábito do encarceramento anterior à condenação definitiva e baseado em meras suspeitas, como representativa causa de desmoralização do povo. Em razão de sua própria natureza, a medida deprime e abate o sentimento de dignidade pessoal daquele que leva vida honesta e inocente, maculando-o com uma marca desmerecida. A opinião dos cidadãos será de que é culpado, mesmo após a sua liberação; restará sempre vivo o martírio da perseguição injusta. Ademais, em função da forma como ocorrido o encarceramento subtrai-se do seio da família um suspeito para submetê-lo às promiscuidades do cárcere - condenando-se a pessoa a irreparável ruína moral. ${ }^{58}$

As palavras de Francesco Carrara, muito embora datem de 1902, ainda são desconcertantemente atuais. Seja pela persistência dessa gravíssima problemática na pauta das modernas democracias, seja pelo caráter humanitário da abordagem do autor, suas palavras permanecem memoráveis e são frequentemente lembradas na doutrina.

A Escola do Positivismo Criminológico, por outro giro, pautando-se na defesa social contra o crime, questionou veementemente a utilização da presunção de inocência no processo penal. A investigação experimental substituiu a indagação puramente racional dos clássicos. O estudo dos fatores antropológicos, sociais e físicos dos criminosos adequava-se ao determinismo da conduta humana: a esta concepção associavase a incoerência de presumir inocente aquele contra quem recaíam graves indícios. Apregoava-se, portanto, o desuso completo ou parcial da presunção de inocência. ${ }^{59}$

Em meados do século XX, com o advento do fascismo, a doutrina insurgiuse contra o conteúdo político da presunção de inocência, que passou a ser utilizada

CARRARA, F. Inmoralidad de la prision provisional. cit., p. 07-10.

Id. Ibid., p. 10.

Afigurava-se consenso no tratamento dos presos em flagrante, réus confessos, reincidentes, delinquentes profissionais, natos e loucos, em favor dos quais seria absolutamente inconveniente presumir-se a inocência. 
expressamente para a defesa social como medida processual diante de grave clamor público. Na Itália, o Código Rocco alargou as hipóteses de prisão obrigatória e automática; desconstituiu o instituto do desencarceramento por decurso de prazo ao suprimir os prazos máximos, e restringiu a análise das condições morais e sociais da pessoa aos casos de emissão e suspensão de mandado facultativo de prisão provisória.

Nesse contexto, a prisão preventiva passava a exercer função de verdadeira medida de prevenção contra os perigosos e suspeitos, a significar autêntica execução provisória da pena. A lógica processual penal conceituada pela Escola Clássica restou patentemente subvertida com a previsão da prisão obrigatória. Solucionava-se, assim, ex lege, a questão dos critérios e funções da prisão preventiva: a obrigatoriedade representava presunção absoluta de periculosidade. ${ }^{60}$

Após o término da Segunda Guerra Mundial, as graves violações dos direitos individuais perpetradas pelo nazi-fascismo resultaram no reconhecimento da presunção de inocência nas Constituições ${ }^{61}$ e Cartas internacionais.

Seguiram a previsão do art. 11, 1 da Declaração Universal dos Direitos do Homem (1948), as disposições do art. $6^{\circ}$ n. 2 da Convenção Européia sobre Direitos Humanos (1950); do art. 14, n. 2, do Pacto Internacional sobre direitos Civis e Políticos (1966), e do art. $8^{\circ}$, n. 2, da Convenção Americana sobre Direitos Humanos (1969).

Desse modo, não se pode ignorar que as garantias constitucionais estão sujeitas aos avanços e retrocessos dos governos e desgovernos políticos. Os valores constitucionais, quando repudiados em nome de controle mais incisivo sobre a sociedade civil, espelham controle estatal na prevenção e repressão dos delitos, e por vezes refletem a função político-retórica do Estado de perpetrar arbitrariedades sob a falsa miragem de cumprimento dos direitos individuais. ${ }^{62}$

A atividade necessária para a regular produção de provas e configuração da responsabilidade pelo crime é a jurisdição; tão somente se considera cometido o delito ou reputa-se culpado certo sujeito após a apresentação de provas pelo órgão acusador e do exercício de defesa. A máxima latina "nulla poena sine judicio" impõe verdadeira submissão à jurisdição, a caracterizar a presunção de inocência do imputado até prova em contrário decretada pela sentença definitiva de condenação. ${ }^{63}$

$60 \quad$ FERRAJOLI, Luigi. op. cit., p. 510.

61 GOMES FILHO, A. M. Presunção de inocência... cit., p. 123-124.

62 FERRAJOLI, Luigi. Diritto e ragione. Trad. port. de Ana Paula Zomer Sica, Fauzi Hassan Choukr, Juarez Tavares e Luis Flávio Gomes. 2. ed. São Paulo: Revista dos Tribunais, 2006. p. 121.

63 Luigi Ferrajoli constata que se trata de princípio fundamental de civilidade, fruto de uma opção garantista a favor da tutela da imunidade dos inocentes, ainda que ao custo da impunidade de algum culpado "(...) se é verdade que os direito dos cidadãos são ameaçados não só pelos delitos mas também pelas penas arbitrárias - que a presunção de inocência não é apenas uma garantia de liberdade e de verdade, mas também uma garantia de segurança ou, se quisermos, de defesa social: da especifica "segurança" fornecida pelo Estado de direito expressa pela confiança dos cidadãos na justiça, e daquela especifica "defesa" destes contrao 
A presunção de inocência relaciona-se imediatamente aos valores ideológicos e humanistas que atuam para garantir os interesses do acusado no processo penal. Corresponde também a uma técnica que contribui para a segurança e certeza do Direito, indicando ao magistrado verdadeira regra de julgamento diante da incerteza: pesa ao órgão acusador o ônus probatório; há que ser superada a presunção iuris tantum de inocência (in dubio pro reo). Diante desta perspectiva, Antonio Magalhães Filho destaca a natureza política do princípio: os direitos individuais são resguardados do interesse coletivo de repressão penal. ${ }^{64}$

Todavia, em posição diametralmente inversa à presunção de inocência tal como vértices opostos de um polígono - a garantia da ordem pública funda-se não no primado da preponderância da Pessoa, em contraposição à coletividade, mas sim, na constatação da existência de interesses orgânicos que, alusivos a todos, se sobrepõe à individualidade do tratamento.

Como vimos no item 3.3, as finalidades açambarcadas pela ideia de ordem pública correspondem quase que completamente ao caráter de defesa social, em seus desdobramentos mais vis, tais como, a exemplaridade, a prevenção especial e o clamor público.

Constata-se, portanto, a inviabilidade da convivência de ambos os conceitos no sistema jurídico. A imediata reação ao delito para a satisfação do sentimento social de justiça abalado pelo crime não se compatibiliza com as garantias decorrentes da limitação da atuação estatal, consubstanciadas na garantia da jurisdicionalidade, do tratamento do acusado como inocente e da preservação de sua liberdade durante o processo.

\subsection{Proporcionalidade}

A proporcionalidade, técnica jurídica a nortear o juízo do magistrado, pode ser desdobrada em três perspectivas diversas: a idoneidade da medida para o alcance do fim almejado; a necessidade de sua adoção e a proporcionalidade em sentido estrito (ponderabilidade dos interesses em conflito).

Em linhas gerais, a idoneidade corresponde à adequação qualitativa, quantitativa e subjetiva da medida, em atenção à viabilidade de concretização do respectivo escopo. A necessidade relaciona-se diretamente ao juízo de intervenção mínima, característico do Direito Penal. A proporcionalidade em sentido estrito, por sua vez, expressa a valoração das consequências do ato em relação à estigmatização jurídica e social que sofrerá o inculpado. ${ }^{65}$

arbitrio punitivo" (FERRAJOLI, Luigi, op. cit., p. 506).

64 GOMES FILHO, A. M. Presunção de inocência... cit., p. 128.

65 BARROS, S. T. O princípio da proporcionalidade e o controle de constitucionalidade das leis restritivas de 
Nos casos em que permitida prisão preventiva, impende sempre avaliar se a medida aplicada no curso da persecução penal não se mostra desproporcional em comparação à pena cominada ao suposto delito. Proibir que a coerção processual resulte mais gravosa que a própria pena é consideração afinada com os ditames da razoabilidade. Igualmente, quando no caso concreto inexiste expectativa de pena privativa de liberdade de cumprimento efetivo, não se autoriza a custódia preventiva.

O princípio da proporcionalidade é desdobramento da dinâmica processual penal que presume a inocência do inculpado, porquanto, os processados haverão de ser tratados como inocentes e nunca equiparados àqueles definitivamente sentenciados. Ademais, o uso da prisão preventiva será inadequado quando fixada pena pouco severa para o delito investigado, porque com frequência, o tempo transcorrido até a realização do julgamento resulta mais alongado que a própria pena prevista. É, portanto, medida lógica que se faça todo o possível para evitar o encarceramento processual quando antevisto que não será imposta pena privativa de liberdade. ${ }^{66}$

O juízo competente deve realizar a comparação da medida de coerção com a pena eventualmente aplicada no caso concreto. Importa acentuar, esse confronto não deve considerar a pena cominada em abstrato pelo tipo penal, mas na verdade, o quantum referente à pena eventualmente aplicável, conforme as contingências particulares do caso.

$\mathrm{O}$ escopo das exigências decorrentes do princípio da proporcionalidade é evitar seja utilizado o encarceramento preventivo como instrumento processual em desfavor do status de inocência do processado, de modo que sofra mal superior à própria sanção penal substantiva.

Contudo, adverte Alberto Bovino, é de ser considerado que uma relação inexorável entre prisão processual e tempo da pena do crime imputado culmina na construção de uma punição antecipada. Em segundo lugar, o princípio da proporcionalidade pode significar não apenas um limite, mas também, uma justificativa para o prolongamento do cárcere, uma vez que nos delitos de alta gravidade o princípio perde seu poder limitativo. Para evitar este último efeito desfavorável existe a garantia de delimitação temporal do cárcere preventivo a um prazo razoável. ${ }^{67}$

A medida extrema estará justificada tão somente diante da completa inexistência de meios para asseguramento do imputado no processo, ou, ainda, quando a pena a ser imposta em eventual condenação for de gravidade tal a ensejar cumprimento obrigatório em regime fechado. Dessa análise estrita da imposição de restrições ao

\footnotetext{
direitos individuais. Brasília: Brasília Jurídica, 1996. p. 72-84.

66 BOVINO, Alberto. Taller regional norte, centro y sur: justicia y derechos humanos: materiales de lectura. Lima: CEAS, 1998. p. 346.

67 BOVINO, Alberto. Taller regional norte, centro y sur: justicia y derechos humanos: materiales de lectura. Lima: CEAS, 1998. p. 347-349.
} 
exercício de um direito constitucionalmente garantido, aferimos a chamada proibição do excesso, conceito relacionado aos imperativos da adequação e necessidade da medida cautelar.

\subsection{Finalidades materiais e processuais da prisão preventiva}

A esta altura, quase ao final deste trabalho, salta aos olhos a relevância de dois argumentos já referidos - autênticos marcos temporais em qualquer estudo sobre prisões provisórias. São conquistas voltadas à humanização da persecução penal, que não obstante ignoradas nos frequentes interregnos históricos de arbítrio, representam espaços de luta na afirmação dos direitos individuais.

O primeiro, inspirado no movimento Iluminista e consolidado nas obras de Hobbes e Beccaria, afirma que a prisão provisória não pode representar antecipação da pena.

Para Hobbes a custódia preventiva: "não se trata, de uma pena, já que a ninguém tal se pode aplicar antes de ser judicialmente ouvido e declarado culpado. Seja qual for o dano infligido a um homem, portanto, por prisão ou confinamento, antes de sua causa ser ouvida, para além do que for necessário para garantir sua custódia, é contrário à lei natural" 68

As palavras de Hobbes voltam-se contra o arbítrio das prisões na Europa, locais onde os cidadãos que deveriam ser amparados pela presunção de inocência, nos calabouços eram tratados com mais rigor que os condenados. O labor dos iluministas, iniciado no século XVIII, perpetuou-se nos ensinamentos da Escola Clássica durante os séculos seguintes e até hoje representa espaço de luta na afirmação dos direitos individuais. Dessa maneira, a não aflitividade da pena por meio do cárcere preventivo consolida o primeiro topoi sob o qual deve repousar qualquer discussão atual: o princípio da não antecipação da pena.

No século XX, como desdobramento deste primeiro princípio, outro lugar comum paulatinamente se consolida no estudo das prisões provisórias. Em atenção à diferenciação entre as finalidades da prisão preventiva passa-se a observar que, se por um lado, algumas buscam assegurar a persecução penal e a aplicação da pena, outras intentam escopos variados. ${ }^{69}$ Malgrado esta distinção não fosse completamente estranha aos autores anteriores à segunda metade do século XX, indubitável que a partir de então passa a ser conceituada com maior exatidão.

\footnotetext{
68 HOBBES, Thomas. Leviathan. Trad. port. de Alex Marins. São Paulo: Martin Claret, 2004. p. 231.

69 CHIAVARIO, M. Processo e garanzie della persona. cit., p. 267-268.
} 
Em relação aos fundamentos materiais que embasam a prisão provisória, inegável a colisão com o modelo garantista. Não é que a previsão da garantia da ordem pública não possa ser compatibilizada com modelos mais próximos do garantismo ideal, mas sim, que este fundamento não pode ser de qualquer maneira sintonizado com a teoria de Ferrajoli. Ainda que pensemos no mais rudimentar dos modelos garantistas nunca imaginaremos um sistema que permita a prisão preventiva sob sete ou oito fundamentos variados, todos resumidos em um: autorização genérica ao alvedrio do julgador, a remeter à triste herança dos modelos totalitários. ${ }^{70}$

Pensando-se na igualdade entre as partes no processo, bem como na correção das desigualdades ínsitas ao procedimento, a permissão da cautela generalizada, nos moldes de um fundamento material e indeterminado, fere a garantia de paridade de armas no processo. Se a natureza inquisitiva do inquérito consolida desigualdade em favor do órgão acusador para que reúna os indispensáveis elementos de prova e viabilize a acusação, a contrapartida é que o tratamento dispensado ao réu presuma sua inocência, restringindo as hipóteses de prisão provisória ao mínimo possível.

Certamente, não são poucos os paradoxos do processo penal: basta imaginar que mesmo presumido inocente o inculpado poderá ser preso em certos casos. Não sem algum estranhamento inicial pode-se encontrar a resposta para este enigma no emprego da dinâmica do favor rei como modo de tratamento do inculpado, bem como nos limites impostos pelos princípios da legalidade e devido processo penal. Entretanto, ao se imaginar a convivência entre os conceitos de ordem pública e processo garantista, chega-se a um paradoxo que nem mesmo a processualística penal poderá equacionar; nem mesmo a dinâmica do favor rei será suficiente para solucionar a incongruência entre Direito e arbítrio. ${ }^{71}$

\subsection{Ordem Pública e motivação}

A valoração probatória do juiz acerca da justa causa para a decretação da prisão, com fulcro na preservação da instrução e aplicação da lei penal, perfaz-se pelo exame objetivo dos indícios presentes. Como já asseverado, a prova que convalida essas modalidades processuais de prisão preventiva é a que demonstra o inculpado

70 Na nota 12 nos remetemos à lição de Del Pozzo que se refere àquele que the parece o melhor critério para a decisão acerca da adoção da prisão preventiva: a prudente sensibilidade do julgador. Todo o esforço do garantismo, como vimos, caminha em sentido contrário: em favor do convencionalismo penal e do cognitivismo processual; contra o subjetivismo inquisitivo e o decisionismo processual.

71 A disciplina legal da prisão preventiva prevê hipóteses tanto para a prisão quanto para a liberdade, sem, todavia, atentar ao fato de que entre ambos os status jurídicos há uma grande lacuna. Relevante discussão atualmente em pauta é aquela acerca da inclusão de medidas cautelares não restritivas de liberdade como alternativa à prisão processual (Projeto de Lei n. 4.208/01). 
comprometendo a colheita de provas, intimidando peritos ou testemunhas ou preparandose para fugir à aplicação da lei. ${ }^{72}$

A demonstração de abalo à ordem pública, no entanto, comporta infindáveis possibilidades de meios probatórios para a confirmação de seus motivos. Aliás, sempre que uma norma é vaga e emprega elementos valorativos que deixam ao arbítrio do juiz a decisão acerca da extensão de seu significado, não há outro caminho senão recorrer à retórica-persuasiva. Como assevera Nicolás Guzmán, a prova perde assim qualquer função cognoscitiva, de sorte que a atividade das partes destinar-se-á basicamente a convencer o julgador, cuja decisão será baseada em juízo de opinião. ${ }^{73}$

Para que a prova possa predicar tanto a hipótese acusatória como a qualificação jurídica que corresponda ao fato comprovado, a norma deve estar dotada de precisão empírica. Há que se referir a fatos exatamente determinados e não a questões valorativas, pois caso contrário, resolver-se-á o caso somente em função de valorações discricionárias do juiz. ${ }^{74}$ Com efeito, a vaguidade normativa possibilita o exercício de poderes discricionários por parte do magistrado no momento de interpretar a norma abstrata. ${ }^{75}$

É certo que as operações mentais realizadas pelo julgador para interpretar o Direito não são lógicas no sentido estrito da palavra (lógica formal), a ponto de ser possível imaginar operações perfeitas de dedução de certas conclusões a partir de determinadas premissas. ${ }^{76}$ Sem dúvida, a eliminação completa do juízo de valor é ideal inalcançável, e invariavelmente fracassará a tentativa de que os juízos correspondam sempre exclusivamente aos fatos.

Entretanto, a evidente constatação da impossibilidade do emprego de juízos formais para a cognição não é suficiente para que seja abandonada a ideia da atividade legislativa como meio para a redução da textura aberta da linguagem a níveis ínfimos.

72 Ambos estes fundamentos para a prisão preventiva, como já se pormenorizou no item 3.2 , não podem ser presumidos de antemão, com base em assertivas materiais, como em referência à gravidade do crime ou periculosidade do agente; dependem, com efeito, do exame das particulares necessidades do caso concreto.

73 GUZMÁN, Nicolás. La verdad em el processo penal: una contribuición a la epistemologia jurídica. Buenos Aires: Editores del Puerto, 2006. p. 68.

74 GUZMÁN, Nicolás. La verdad em el processo penal: una contribuición a la epistemologia jurídica. Buenos Aires: Editores del Puerto, 2006. p. 69.

75 Perelman sustenta outro embasamento para a prova, cuja função seria meramente argumentativa, e por meio dela somente se poderia atingir o convencimento de quem deve resolver o caso (Tratado da argumentação - A nova retórica, trad. port. de Maria Ermantina Galvão, São Paulo, Martins Fontes, 1999). Diversamente, a concepção aqui esposada é que a prova tem função cognoscitiva; trata-se, portanto, de instrumento para chegar-se à verdade de uma determinada hipótese. A prova exerce papel não apenas persuasivo, mas como fator de conhecimento (fonte de conhecimento de fatos passados) e justificação (decisões serão válidas desde que contenham explicação racional das inferências realizadas, baseadas precisamente nos elementos de prova reunidos no processo).

76 BOBBIO, Norberto. El problema del positivismo juridico. México: Fontamara, 1999. p. 31. 
Todos os recursos técnicos à disposição do legislador para auferir a maior precisão possível devem ser utilizados, sob pena de restar comprometido o fundamento convencionalista da estrita legalidade. Como afirma Ferrajoli, a relevância penal de um fenômeno não repousa nem na verdade, justiça, moral ou natureza, mas somente nas previsões empíricas determinadas na lei. ${ }^{77}$

A prova opera, então, como elemento de justificação racional do fato, concatenação e combinação das inferências em razão das quais a asserção do fato é assumida como verdadeira. A racionalidade não apresenta somente as formas de demonstração matemática ou dedutiva, pois, ao contrário, pode-se falar de uma racionalidade menos rígida que mantenha os cânones da coerência e da validez lógica, e que, portanto, configure modos de razoamento controláveis e não reduzíveis a mera argumentação persuasiva. ${ }^{78}$

A aceitação de uma hipótese como verdadeira depende antes da coerência entre o material probatório e a hipótese confirmada e também da maior capacidade explicativa desta hipótese em relação às outras, do que de um mero poder persuasivo dos argumentos. $\mathrm{O}$ controle racional da motivação contida na sentença estará observado se estes critérios de verdade forem empregados.

A previsão de figuras elásticas e indeterminadas, característica dos sistemas anti-garantistas decisionistas, associa-se à retórica argumentativa dos juízos de valor. A decisão pautada neste padrão será desprovida de racionalidade e impossibilitará o controle do processo pelas partes - a crítica da aplicação das regras de lógica e da incorreta utilização dos elementos probatórios, efetivada por meio do contraditório, estará notadamente prejudicada.

A retórica meramente persuasiva da decisão, portanto, limita também o exercício do contraditório. Esta garantia, que constitui o melhor método para o descobrimento da verdade, tanto submete à prova a tese de acusação, como oferece a possibilidade de ser refutada. É a técnica que permite o conhecimento da verdade (ao menos relativamente), não em forma unidirecional, mas por meio do confronto de hipóteses contrárias entre si que tentam prevalecer. $\mathrm{O}$ método não é constituído sob a prerrogativa de favorecer uma das partes em seu direito de defesa, vai além, à medida que se constitui como instrumento para o conhecimento dos fatos.

FERRAJOLI, Luigi. op. cit, p. 39.

78 Michelle Taruffo não nega que existam fatores persuasivos ou retóricos na assunção da prova em juízo; o problema, porém, não seria estabelecer se esses fatores existem, mas sim se são tão importantes a ponto de justificar uma teoria retórica da prova que possa ser assumida como dominante ou inclusive como teoria exclusiva e única da prova. É nesse plano que a teoria da prova como argumento persuasivo encontra dificuldades insuperáveis (TARUFFO, Michelle. La prueba de los hechos. Trad. esp. Jordi Ferrer Beltrán. Madri: Trotta, 2002. p. 350). Como adverte Nicolás Guzmán, nas alegações das partes, por exemplo, é possível encontrar elementos persuasivo-retóricos. Contudo, no processo falam outras pessoas: testemunhas, peritos, etc., e estes não pretendem persuadir ninguém, mas simplesmente contam o que sabem (GUZMÁN, Nicolás. op. cit., p. 104). 
Se o ideal de igualdade no processo, expresso na garantia da paridade de armas entre acusação e defesa, é aviltado pela indeterminação das hipóteses de prisão, também não há dúvida que as bases para o contraditório pressupõem a racionalidade no discurso e a cognição afeita aos esquemas racionais de fundamentação.

A garantia da ordem pública, portanto, sobre não favorecer a racional demonstração e justificação do raciocínio desenvolvido pelo juiz, ainda viola as garantias constitucionais da paridade de armas no processo e do contraditório. A vaguidade do termo dá azo a inúmeras interpretações, constantemente identificadas às medidas de defesa social (item 3.3). Neste caso, a fundamentação da prisão preventiva rompe os padrões de legalidade e certeza jurídica, invariavelmente autorizando os juízes à formulação de definições puramente persuasivas, que encobrem juízos de valor.

5. Conclusões

5.1. O ser humano é o fundamento primeiro e a causa final do Direito. Logo, o respeito ao homem e à sua liberdade são limites impostos a qualquer legislador.

5.2. O escopo de prevenir um perigo concreto - obstar um dano jurídico provável que impossibilite a apuração da verdade e o provimento justo - é o ponto de convergência de todas as medidas cautelares restritivas de liberdade. Todavia, o risco representado pelo processo, incumbe majoritariamente ao Estado. A restrição do status libertatis exige a presença de cinco características essenciais das medidas cautelares: judicialidade, instrumentalidade, urgência, provisoriedade e aparência.

5.3. Toda prisão que não seja cumprimento de sentença penal condenatória irrecorrível deve ser exclusivamente cautelar, sob condição de representar punição antecipada. Se os fundamentos da pena consistem tanto na exigência de justiça, quanto em sua respectiva utilidade, a custódia cautelar, por outro lado, constitui instrumento em favor do processo.

5.4. A ordem pública é o status quo de circunstâncias da vida que representem a normalidade da coletividade de uma dada sociedade (tranquilidade e paz social que permitam o desenvolvimento das relações sociais e econômicas). O conceito ocupa lugar de standard jurídico - noção indeterminada que busca estabelecer um padrão de normalidade, reflexo da tentativa de atribuir normatividade a critérios técnicos ou sociais. No processo penal está associada aos seguintes entendimentos: 
necessidade de pôr fim a uma desordem; emoção causada diante de qualquer crime violento e abominável; necessidade de proteger a coletividade das repercussões imediatas e excessivas da multidão efervescente; necessidade de proteger outras eventuais vítimas futuras; evitar a reiteração da infração e proteger o autor.

5.5. As prisões provisórias, conforme a evolução da jurisprudência do Supremo Tribunal Federal, adstringem-se à excepcionalidade dos casos, diretriz nem sempre observada pelos nossos Tribunais. Com base na garantia da ordem pública, aludese com frequência a aspectos relacionados ao delito, ao agente ou ao processo, para justificar a prisão.

5.6. A prisão preventiva deve estar sujeita ao exame dos pressupostos para as medidas cautelares (fumus boni iuris e periculum in mora); a análise dos limites objetivos, subjetivos e temporais; a avaliação dos requisitos (devem ser apenas aqueles processuais: conveniência da instrução criminal e asseguração da aplicação da lei penal).

5.7. Para que a prova não careça de função cognoscitiva e para que possa predicar tanto a hipótese acusatória como a qualificação jurídica que corresponda ao fato comprovado, a norma deve estar dotada de precisão empírica. Há que se referir a fatos exatamente determinados e não a questões valorativas, pois, em caso contrário, a questão se resolverá somente em função de valorações discricionárias do juiz. Com efeito, a indeterminação normativa possibilita o exercício de poderes discricionários por parte do julgador no momento de interpretar a norma abstrata.

5.8. A previsão de conceitos elásticos e indeterminados como a ordem pública, característica dos sistemas anti-garantistas decisionistas, obriga as partes a recorrer ao discurso retórico-persuasivo para convencer o juiz. Rompem-se, assim, os padrões de legalidade e certeza jurídica, invariavelmente autorizando os magistrados à formulação de definições puramente persuasivas que encobrem juízos de valor. Ademais, impossibilita-se o controle do processo pelas partes: a crítica da aplicação das regras de lógica e da incorreta utilização dos elementos probatórios, feita por meio do contraditório, estará notadamente prejudicada.

5.9. A mera harmonização da garantia da ordem pública, à luz dos direitos fundamentais 
é impraticável, tanto em função do antagonismo entre a gênese dos conceitos, como também pela profunda desigualdade instituída pela terminologia no tratamento da defesa e da acusação. O posicionamento defendido neste estudo é de que a garantia da ordem pública seja extirpada definitivamente da lei processual penal.

São Paulo, junho de 2009.

\section{Referências}

ALMEIDA JÚNIOR, João Mendes. O processo criminal brasileiro. 4. ed. São Paulo: Freitas Bastos, 1959. v. 1.

BARATTA, Alessandro. Criminologia critica e critica del diritto penale. Trad. port. de Juarez Cirino dos Santos. 2. ed. Rio de Janeiro: Freitas Bastos, 1999.

BARROS, Romeu Pires de Campos. Processo penal cautelar. Rio de Janeiro: Forense, 1982.

BARROS, Suzana de Toledo. O princípio da proporcionalidade e o controle de constitucionalidade das leis restritivas de direitos individuais. Brasília: Brasília Jurídica, 1996.

BECCARIA, Cesare. Dei delitti e delle pene. Trad. port. de Alexis Augusto Couto de Barros. São Paulo: Quartier Latin, 2005.

BECHARA, Fábio Ramazzini. Prisão cautelar. São Paulo: Malheiros, 2005.

BOBBIO, Norberto. Il problema del positivismo giuridico. 6. ed. México: Fontamara, 1999.

BOVINO, Alberto. Taller regional norte, centro y sur: justicia y derechos humanos: materiales de lectura. Lima: CEAS, 1998.

CARNELUTTI, Francesco. Principi del Processo Penale. Nápoles: Morano, 1961.

CARRARA, Francesco. Inmoralidad de la prision provisional. Trad. esp. de Manuel Quintanar. Cuadernos de politica criminal, Madrid, n. 67, 1999.

CHIAVARIO, Mario. Libertà personale e processo penale. In: L'Indice Penale, Pádua, ano XXI, n. $2,1987$.

Processo e garanzie della persona. 2. ed. Milão: Giuffrè, 1982. v. 2.

DELMAS-MARTY, Mireille (Org.). Procédures pénales d'Europe. Trad. port. de Fauzi Hassan Chouckr, e Ana Cláudia Ferigato Choukr. Rio de Janeiro: Lúmen Júris, 2005.

DELMANTO JUNIOR, Roberto. As modalidades de prisão provisória e seu prazo de duração. 2. ed. Rio de Janeiro: Renovar, 2001.

FARIA, José Eduardo Campos de Oliveira. Retórica política e ideologia democrática. São Paulo: Tese, 1982. 
FERNANDES, Antonio Scarance; GOMES FILHO, Antonio Magalhães; GRINOVER, Ada Pellegrini. As nulidades no processo penal. 10. ed. São Paulo: Revista dos Tribunais, 2007.

FERNANDES, Antonio Scarance. Funções e limites da prisão processual. Revista Brasileira de Ciências Criminais, São Paulo, n. 64, 2007.

FERRAJOLI, Luigi. Diritto e ragione. Trad. port. de Ana Paula Zomer Sica e Fauzi Hassan Choukr, Juarez Tavares e Luis Flávio Gomes. 2. ed. São Paulo: Revista dos Tribunais, 2006.

GOMES FILHO, Antonio Magalhães. Presunção de inocência: princípios e garantias. In: ESCRITOS em Homenagem a Alberto Silva Franco. São Paulo: Revista dos Tribunais, 2003.

. Presunção de inocência e prisão cautelar. São Paulo: Saraiva, 1991.

GUÉRY, Christian. Détencion provisoire. Paris: Dalloz, 2001.

GUZMÁN, Nicolás. La verdad em el proceso penal: una contribución a la epistemología jurídica. Buenos Aires: Editores del Puerto, 2006.

HOBBES, Thomas. Leviathan. Trad. port. de Alex Marins. São Paulo: Martin Claret, 2004.

LOPES JUNIOR, Aury Celso Lima. Medidas cautelares no direito processual penal espanhol. Revista da Associação dos Juizes do Rio Grande do Sul, Porto Alegre, ano XXIV, n. 69, 1997.

MIRABETE, Julio Fabbrini. Mamual de direito penal. 17. ed. São Paulo, Atlas, 2001. v. 1. Processo penal. 16. ed. São Paulo: Atlas, 2004.

MAGALHÃES NORONHA, Edgard. Direito penal: parte geral. 10. ed. São Paulo: Saraiva, 1973.

NUCCI, Guilherme de Souza. Código de processo penal comentado. 3. ed. São Paulo: Revista dos Tribunais, 2004.

PERELMAN, Chaïm; OLBRECHTS-TYTECA, Lucie. Tratado da argumentação. A nova retórica. Trad. port. de Maria Ermantina Galvão. São Paulo: Martins Fontes, 1999.

PISAPIA, Gian Domenico. Compendio di procedura penale. Pádua: CEDAM, 1988.

PITOMBO, Sérgio Marcos de Moraes. Prisão preventiva em sentido estrito. In: PENTEADO, Jacques de Camargo (Coord.). Justiça Penal. n.7. São Paulo: Revista dos Tribunais, 2000.

DEL POZZO, Carlo Umberto. La liberta personale nel processo penale Italiano. Turim: UTET, 1962.

ROMERO, Cecília Sánchez. La prisión preventiva en un estado de derecho. Revista de la Asociación de Ciências Penales de Costa Rica, São José, ano IX, n. 14, 1997.

SARTRE, Jean-Paul. L'Existencialismme est um Humanisme. São Paulo: Abril Cultural, 1973.

SANGUINÉ, Odone. A inconstitucionalidade do clamor público como fundamento da prisão preventiva. In: SHECAIRA, Sérgio Salomão (Org.). Estudos criminais em homenagem a Evandro Lins e Silva. São Paulo: Método, 2001. 
Prisión provisional y derechos fundamentales. Valência: Tirant, 2003.

SHECAIRA, Sérgio Salomão. Criminologia. São Paulo: Revista dos Tribunais, 2004.

SZNICK, Valdir. Liberdade, prisão cautelar e temporária. 2. ed. São Paulo: EUD, 1995.

TARUFFO, Michele. La prueba de los hechos. Trad. esp. de Jordi Ferrer Beltrán. Madri: Trotta, 2002.

TOURINHO FILHO, Fernando da Costa. Manual de processo penal. 9. ed. São Paulo: Saraiva, 2007.

TUCCI, Rogério Lauria. Direitos e garantias individuais no processo penal brasileiro. 3. ed. São Paulo: Revista dos Tribunais, 2009

MORAES, Maurício Zanóide de. Presunção de inocência no processo penal brasileiro: análise de sua estrutura normativa para a elaboração legislativa e para a decisão judicial. 2008. Tese (Doutorado) - Faculdade de Direito, Universidade de São Paulo, São Paulo. 